\title{
Laboratory simulations of the transformation of peas as a result of heating: the change of the molecular composition by DTMS
}

\author{
F. Braadbaart ${ }^{\mathrm{a}, \mathrm{b}, *}$, J.J. Boon ${ }^{\mathrm{a}}$, J. van der Horst ${ }^{\mathrm{a}}$, \\ P.F. van Bergen ${ }^{b, 1}$ \\ a FOM Institute for Atomic and Molecular Physics, Kruislaan 407, \\ 1098 SJ Amsterdam, The Netherlands \\ ${ }^{\mathrm{b}}$ Department of Earth Sciences-Geochemistry, Faculty of Geosciences, \\ Utrecht University, P.O. Box 80021, 3058 TA Utrecht, The Netherlands
}

Accepted 7 January 2004

\begin{abstract}
Peas (Pisum sativum L.) consist mainly of cotyledons and their bulk material is starch and proteins. Their structure is rather confined. Peas were heated at temperatures ranging from 130 to $700{ }^{\circ} \mathrm{C}$ under anoxic conditions for maximum $2 \mathrm{~h}$. For each temperature a separate experiment was carried out in a pre-heated oven. Direct temperature-resolved mass spectrometry (DTMS) under electron impact (EI) and chemical ionization $\left(\mathrm{CI}, \mathrm{NH}_{3}\right.$ ) conditions measured the molecular composition of each solid residue. Fourier-transform infrared (FTIR) spectroscopy was carried out on residues heated at higher temperatures. The resulting solid products of the heating process still show the original markers for polysaccharides and proteins up to $270^{\circ} \mathrm{C}$. Concurrently three phases can be considered, each characterized by its own products. The first phase, from 270 up to $310^{\circ} \mathrm{C}$, shows monosaccharides, protein fragments and aromatic compounds. The second phase, from $310^{\circ} \mathrm{C}$ up to a transitional stage from 400 to $440^{\circ} \mathrm{C}$, releases various aromatic and heterocyclic compounds. The third phase at higher temperatures shows a highly $\mathrm{C}$-enriched product that releases $\mathrm{CO}, \mathrm{CO}_{2}, \mathrm{HCN}, \mathrm{SO}$ and $\mathrm{SO}_{2}$. The $\mathrm{EI}$ and $\mathrm{CI}$ experiments fail to discriminate between the pyrolysis products of polysaccharides and proteins between 250 and $400^{\circ} \mathrm{C}$. FTIR shows in this temperature range the development of an aromatic network. An earlier classification based on the changes of the physical and bulk chemical properties as a function of the temperature corresponds well with the classification based on the molecular
\end{abstract}

\footnotetext{
* Corresponding author.

E-mail address: brabra@wxs.nl (F. Braadbaart).

${ }^{1}$ Flow Assurance, Shell Global Solutions International B.V., P.O. Box 38000, 1030 BN Amsterdam, The Netherlands.
} 
changes. Residues of heated peas, usually called carbonized peas, are found in the archaeological record. Our study suggests that peas should have been heated up to least $310^{\circ} \mathrm{C}$ before their residues survive natural degradation processes.

(c) 2004 Elsevier B.V. All rights reserved.

Keywords: Heat treatment; DTMS; Carbonization; Pea; Starch; Protein

\section{Introduction}

Fruits and seeds are of particular interest for archaeology, as they might provide insights into the agriculture and the diet of the people who used them. Plant parts are often found in the archaeological record as charred remains of wood, fruits or seeds [1]. These charred remains result from a series of processes called the formation processes [2,3], which include carbonization, deposition in the soil, post-depositional alteration, excavation and analysis. To understand the effect of these processes on carbonized material it is necessary to know more about the composition of the fruits and seeds just after carbonization took place and thus before they could enter a depositional stage. This study reports on laboratory simulations of the conversion of fresh to carbonized seeds as a result of progressive heating and focuses on the molecular changes that have occurred.

Because the terms carbonization and char are ill defined and have different meanings in the different fields of research [4], the process of heating has been defined as the product resulting from heat treatment: the solid residue.

The objective of this study is assessing the molecular changes of the organic matter in the seeds of peas that occur during heating under anoxic conditions at atmospheric pressure. The intact peas were heated at a range of temperatures (i.e. $130-700{ }^{\circ} \mathrm{C}$ ). The by far largest structural components of peas are the cotyledons, which consist mainly of starch with amylose, a polyglucan, as its main component. Amylose has been studied extensively using direct temperature-resolved mass spectrometry (DTMS) under chemical ionization conditions and the typical mass peaks and their structure are well known $[5,6]$. The pyrolysis and carbonization of cellulose, which has a strong structural resemblance to amylose, has been studied extensively by DTMS, Py-GC-MS, Fourier-transform infrared (FTIR) and NMR ([7-9] and references therein). These studies provided detailed information on the processes that lead to the aromatized residual materials. Similar studies (unpublished) on amylose yielded very comparable results, although thermal dissociation reactions took place at a lower temperature (a difference of ca. $\left.60^{\circ} \mathrm{C}\right)$.

In the present study the assessment of the molecular changes as a result from heating of the polysaccharide/protein rich cotyledons of peas was performed with DTMS. The experiments were carried out under chemical ionization (CI) and low voltage ionization (EI) conditions. The changes as a result of heating of the internal and external morphology, the elemental composition and the vitrinite reflectance of the peas have been presented in an earlier study [4]. 


\section{Material and methods}

\subsection{Samples}

The Centre for Genetic Resources in Wageningen, The Netherlands (CGN) supplied the following three Dutch varieties of pea (Pisum sativum L.): 'Graauwe Erwt' (GE; CGN 10198), 'Noord-Hollandse Rozijnerwt' (NHR; CGN 10293) and 'Wijker Vale' (WV; CGN 10312). The flowers of these varieties are red and the outside colour of their seeds is generally brown and the surface is wrinkled. Based on these features they belong to the field pea ( $P$. sativum ssp. arvense) [10]. All these varieties were sown in the Hortis Botanicus of the University of Leiden. About 2 months after harvesting in the summer of 1999, peas of the variety GE were used for heat treatment experiments without any further pre-treatment. Inside the seed coat two cotyledons with the storage parenchyma cells are present. These cells contain large starch grains, numerous protein bodies and small deposits of fats [11,12]. The average chemical composition of peas is shown in Table 1 after Belitz and Grosch [13]. The digestible carbohydrate is mainly starch (ca. 42\%) [14]. However, it has been shown that for field peas the amount of starch is reduced to ca. $20 \%$, while the amount of hemicelluloses has increased to $30-40 \%$ at the same time [15].

Professor Dr. C.C. Bakels from the Faculty of Archaeology of Leiden University donated a sample of peas from the archaeological record that had been exposed to heat. This sample is referred to as H414. The archaeological peas were excavated from a site in a loess soil in Hienheim (Northern Bavaria, Germany) in pit 414 . The age of the peas as determined by ${ }^{14} \mathrm{C}$ was 5100 years cal. BC [16].

As a reference compound a sample of a pea protein isolate with $90 \%$ protein, Pisane HD, was kindly supplied by Cosucra, SA (Belgium). The sample is referred to as Pisane HD.

\subsection{Heat treatment}

For each experiment 10 intact peas were placed in an open Pyrex vessel and inserted in a $30 \mathrm{~cm}$ long Pyrex tube $(\varnothing 2.3 \mathrm{~cm})$ at ca. $18 \mathrm{~cm}$ from the inlet. The tube was placed in a pre-heated Carbolite tube oven (model MTF 12/38/250). During the experiments the rate of heating of the oven was limited by setting a ramp rate of $2{ }^{\circ} \mathrm{C} \mathrm{min}^{-1}$. In initial experiments the samples were heated at an oven temperature of $250^{\circ} \mathrm{C}\left(T_{\text {oven }}=250^{\circ} \mathrm{C}\right)$ as a function

Table 1

Chemical composition of peas ${ }^{\mathrm{a}}$

\begin{tabular}{lr}
\hline & Percentage $^{\mathrm{b}}$ \\
\hline Crude protein & 25.7 \\
Lipid & 1.4 \\
Digestable carbohydrate & 53.7 \\
Crude fibre & 18.7 \\
Minerals & 3.0 \\
\hline
\end{tabular}

${ }^{a}$ From Belitz and Grosch [13].

${ }^{\mathrm{b}}$ The results are average values given as wt.\% dry matter. 
of time for $7.5,15,22.5,30,37.5,45,60$ and $120 \mathrm{~min}$ to determine the optimal heating time. Based on these initial experiments peas were heated for each experiment for $60 \mathrm{~min}$ at one of the following temperatures: 130, 160, 190, 220, 235, 250, 270, 290, 310, 340, 370, $400,440,500,600$ and $700{ }^{\circ} \mathrm{C}$ under a constant flow $\left(150 \mathrm{ml} \mathrm{min}^{-1}\right)$ of $\mathrm{N}_{2}$ at atmospheric pressure. The samples of the solid residues of the peas as a result of the heating for $60 \mathrm{~min}$ will be referred to as residue 130, residue 160, etc. The Pyrex vessel with the peas or the pea residues was weighed before and after heating, in order to determine the percentage weight loss. Gases and volatiles were vented and not further investigated.

The reference compound Pisane HD was heated for 60 min under the same experimental conditions at $250,310,370,400,440$ and $500{ }^{\circ} \mathrm{C}$.

\subsection{Direct temperature-resolved mass spectrometry}

\subsubsection{Chemical ionization}

The samples, cotyledons of two untreated peas and residues $130-400^{\circ} \mathrm{C}$, were measured in triplicate using a JEOL JMS-SX/SX102A tandem double focusing mass spectrometer with $\mathrm{B} / \mathrm{E} / \mathrm{B} / \mathrm{E}$ geometry. Powered sample was deposited on the platinum/rhodium (90:10) filament of a probe, which was inserted directly into the ion source of the mass spectrometer. The filament was resistively heated by ramping the current with a rate of $0.5 \mathrm{~A} \mathrm{~min}^{-1}$. Using this ramp the temperature was linearly increased from ambient to approximately $800^{\circ} \mathrm{C}$ in $2 \mathrm{~min}$. Desorbed and pyrolysed material was ionized by positive ammonia chemical ionization and accelerated to $8 \mathrm{kV}$. The mass spectrometer was scanned over an $\mathrm{m} / \mathrm{z}$ range of 60-1000 using a $1 \mathrm{~s}$ cycle time.

\subsubsection{Electron impact (EI)}

Triplicate EI measurements of samples of cotyledons of untreated peas and residues 130-700 were undertaken using the same set up as described above. Ions were generated using $16 \mathrm{eV}$ electron ionization. The mass spectrometer was scanned over an $\mathrm{m} / \mathrm{z}$ range of 20-1000 using a $1 \mathrm{~s}$ cycle time.

\subsection{Multivariate analysis}

Software has been developed at FOM Institute AMOLF to extract principal components from sets of DTMS spectra. In this study the FOMpyroMap multivariate program and the ChemomeTricks program were used for the calculations. As samples were analysed in triplicate, it was possible to perform discriminant analysis (DA). DTMS spectra of the samples are grouped and plotted in the DA space using scores (score maps) and loading plots recalculated as partial mass spectra of the discriminant functions. Interpretation of the chemical significance of those partial mass spectra makes it possible to evaluate the molecular significance of the distribution and grouping of the samples in the DA space [17].

\subsection{FTIR}

Fourier-transform infrared spectrometry was performed using a FTS-6000 Bio-Rad FTIR imaging system (Bio-Rad, Cambridge, MA, USA), consisting of a Michelson interferometer 
(Bio-Rad FTS-6000), an IR microscope (Bio-Rad UMA-500) and a MCT narrow band detector. A sample of powdered whole grains of Pisane HD or peas was applied onto a Graseby Specac PN 2550 diamond cell (Graceby Specac, Orpington, Kent, UK) and analysed in transmission mode at a resolution of $4 \mathrm{~cm}^{-1}$. Data were processed using Win-IR 2.5 software of Bio-Rad.

\section{Description of the molecular composition of untreated material}

\section{1. $\mathrm{DTMS}-\mathrm{CI}-\mathrm{NH}_{3}$}

\subsubsection{Untreated peas}

Polysaccharides, proteins and lipids (Table 1) are the common constituents of the cotyledons of peas. The polysaccharides are represented mainly by starch and hemicelluloses [14]. The proteins legumin, vicilin and albumin are the storage proteins of peas [13]. DTMS-CI-NH $\mathrm{N}_{3}$ experiments were carried out on samples of cotyledons of peas to study their chemical nature. The total ion current (TIC) (insert Fig. 1) of the DTMS-CI-NH experiment for the sample of untreated peas shows a sharp product distribution with the apex $\left(T_{\max }\right)$ at 52 scans. The mass spectrum of the untreated peas (Fig. 1) shows the polymer characteristics of starch. The main mass peak is $\mathrm{m} / \mathrm{z}, 180$, the ammonium ion adduct of 1,6-anhydroglucose (levoglucosan) followed by the series of masses at $\mathrm{m} / \mathrm{z} 342,504$, 666 and 828 corresponding to oligosaccharides with a 1,6-anhydrohexose terminal group [5]. Other significant mass peaks are the dehydration products $\mathrm{m} / z .162$ (ammonium adduct of dianhydrosugars) and 144 (ammonium adduct of trianhydrosugars). Additional series of ions are present with a starting mass of $\mathrm{m} / \mathrm{z} 222$ and 240. These two series, with a relative low intensity, i.e. $\mathrm{m} / \mathrm{z} 222,384,546,708$ and $\mathrm{m} / \mathrm{z}$ 240, 402, 564, 726, 888 represent series of oligosaccharides with attached ring-cleavage fragments [18].

The hemicelluloses are represented by anhydropentosans (xylans) in the series $\mathrm{m} / \mathrm{z}, 150$, 282, 414 and 546 [6]. A dehydration product is $\mathrm{m} / \mathrm{z}, 132$. The peaks at $\mathrm{m} / \mathrm{z}, 146$ and 164 are indicative of the presence of deoxyhexose residues. The peak at $m / z 134$ is a hexosan pyrolysis product formed due to the presence of inorganic material in the sample [19], in this case of peas potassium (Table 2).

It is known that proteins could reach a content of $25 \mathrm{wt} . \%$ or more in the cotyledons of peas (Table 1). However, due to the high relative abundance of polysaccharide pyrolysis products in the CI spectrum (Fig. 1) no clear sign of markers of protein is observed. However, on the high temperature side of the TIC trace the summated spectrum, from scan 55 to 70 ,

Table 2

Mineral content in peas (Pisum sativum) var. GE

\begin{tabular}{lc}
\hline & wt.\% \\
\hline $\mathrm{K}_{2} \mathrm{O}$ & 1.00 \\
$\mathrm{P}_{2} \mathrm{O}_{5}$ & 0.54 \\
$\mathrm{CaO}$ & 0.01 \\
$\mathrm{~S}$ & 0.27 \\
\hline
\end{tabular}




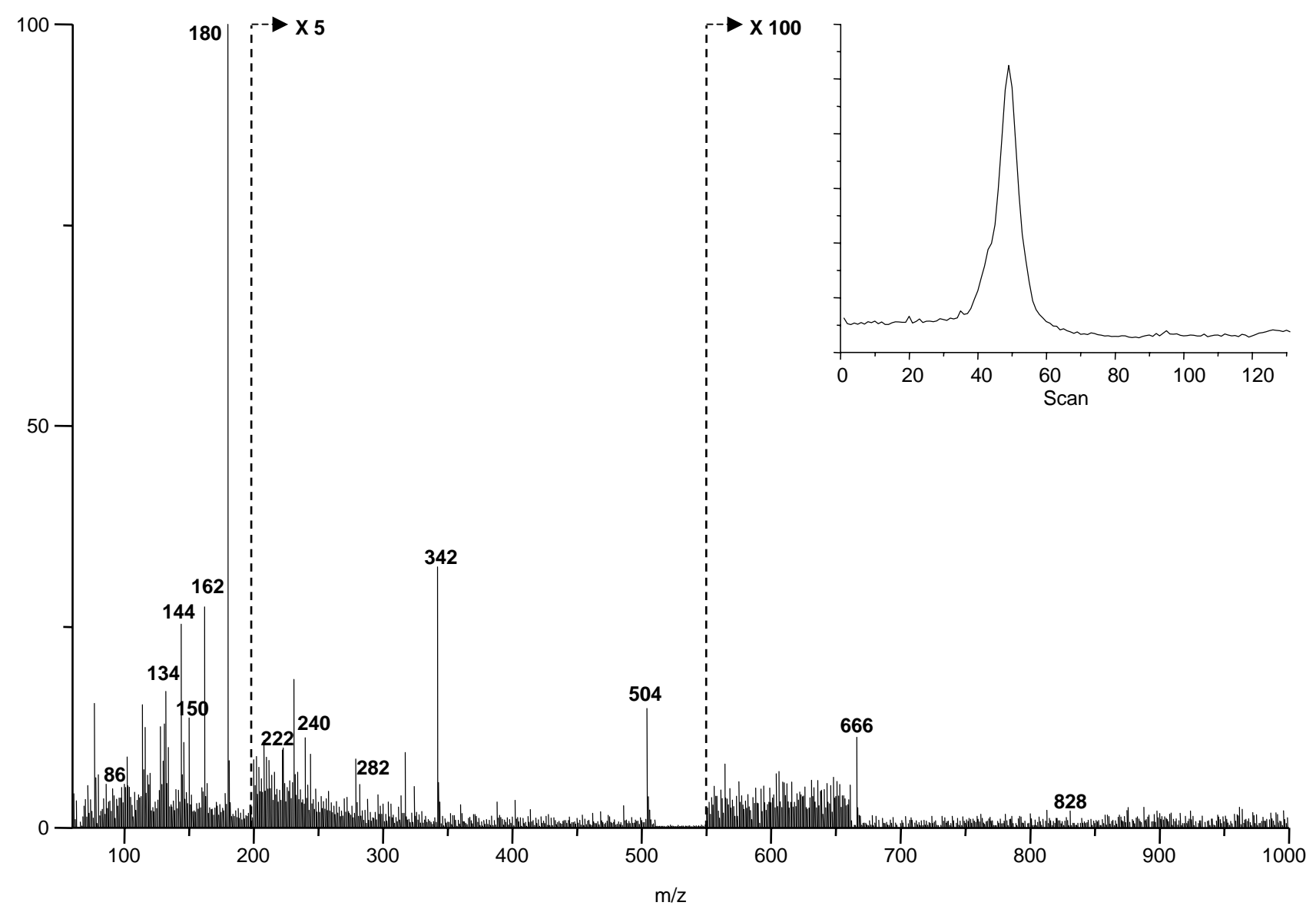

Fig. 1. DTMS (CI) mass spectrum of untreated Pisum sativum (var. GE), insert: TIC. 


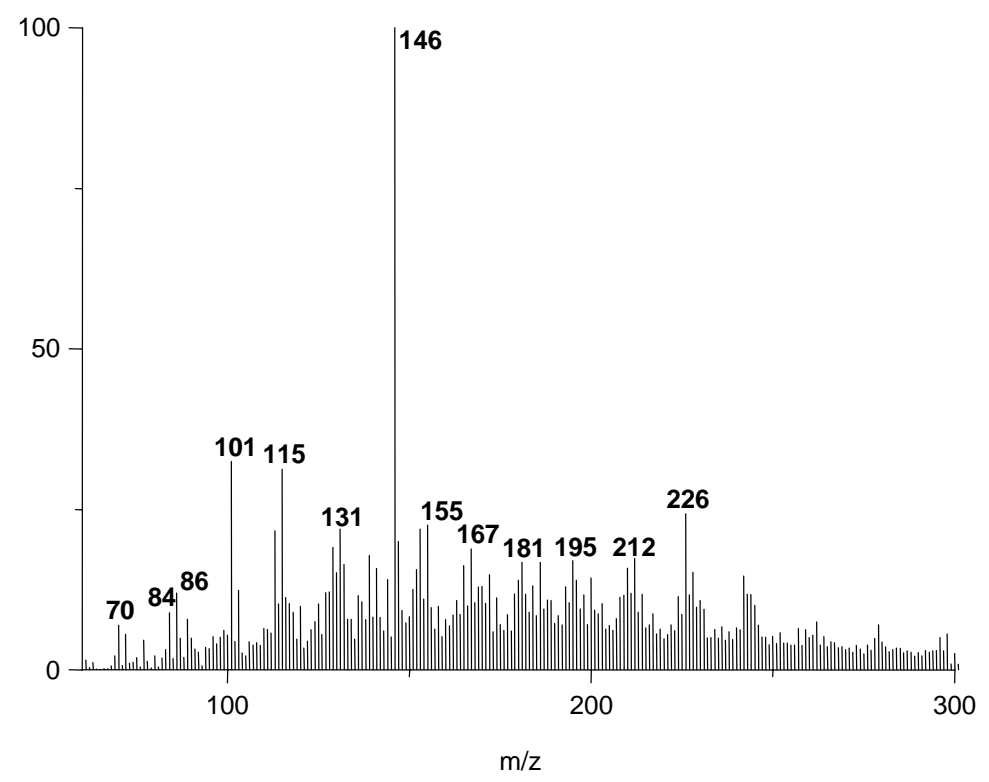

Fig. 2. DTMS (CI) mass spectrum of Pisane HD (pea protein isolate).

shows that ions are released (not shown) attributed to proteins, like $m / z 84,86,101,115$, 131 and 146 [20].

No information was obtained about the presence of lipids, as they ionize poorly under these conditions.

\subsubsection{Pisane $H D$}

The relative abundance of polysaccharide pyrolysis products did not allow for a clear recognition of protein markers. Therefore, an experiment with a sample of protein isolate of peas was carried out. The CI spectrum (Fig. 2) of Pisane HD shows an envelope of mass peaks $m / z$ 100-240. Many of these masses have been found previously in protein rich material [20,21], of which the most prominent are $m / z 70,84,86,101,103,115,131,139$, $141,146,153,155,165,167,181,186,195,212$ and 226. These masses are considered as a fingerprint of proteins in the CI spectra of peas. Masses $\mathrm{m} / \mathrm{z}$ 84, 101, 115 and 146 have been tentatively attributed to Lys and Glu, amino acid amides [20]. The ion series $m / z 139$, $153,167,181$ and 195 have been proposed as unsaturated imidazole compounds originating from proteins [22]. As explained above the presence of proteins in cotyledons of peas is difficult to observe.

\subsection{DTMS-EI}

\subsubsection{Untreated peas}

DTMS under EI conditions has the potential to reveal more information on the proteins and lipids in peas, because the sugar pyrolysis products are strongly fragmented under these 

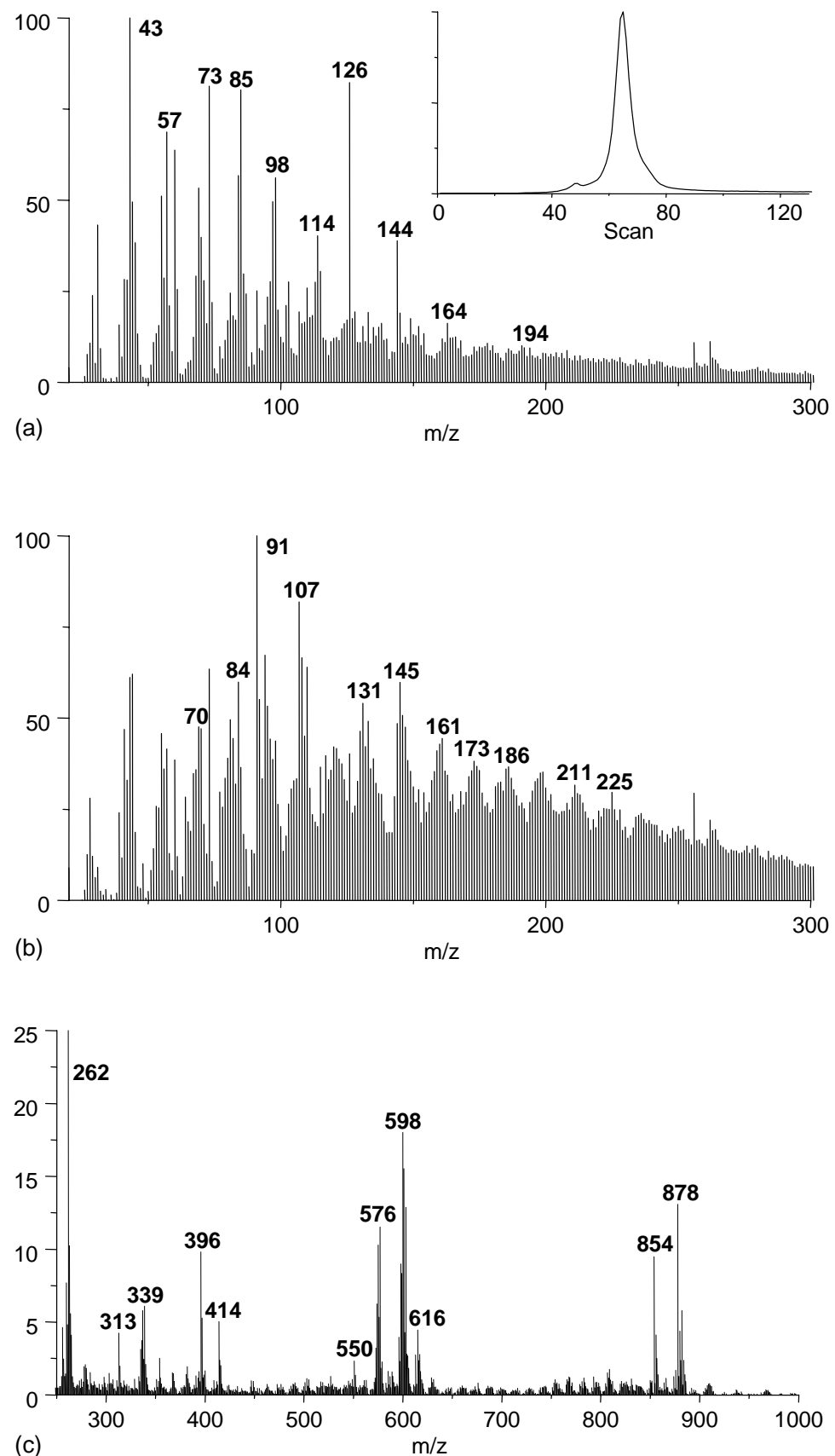

Fig. 3. DTMS (EI) measurements of untreated Pisum sativum (var. GE). (a) mass spectrum, insert: TIC; (b) mass spectrum (scans 70-80) showing protein markers and (c) mass spectrum (scans 40-55) showing lipids. 
conditions. A lower peak at the early stage of the temperature ramp and a main peak at a higher temperature characterize the TIC. The trace shows a sharp product distribution with the apex of the main peak at 62 scans (insert Fig. 3a).

The EI spectrum of the untreated pea (Fig. 3a) shows the characteristics of polysaccharides (starch and hemicelluloses), proteins and lipids. The masses representing starch are the fragment ions $m / z$ 43, 57, 60, 73, 98, 126 and 144, derived from hexosesugars [23-27]. Pentosesugars representing hemicelluloses are anhydroxyloses with $m / z$, 85 and 114 [23,28].

Low voltage EI proteins markers are usually found in the range of $m / z$ 130-220 [21]. Typical ions in this range and the lower mass range are present in the spectrum of Fig. 3a, but are more prominent in the summated spectrum from the high temperature side (between scans 70 and 80) of the TIC trace (Fig. 3b). Visible are $m / z 69$ (Val, Leu, Lys, Gln); 70, 154, 194 (Pro, Arg, Lys); 84 (Glu, Val, Lys) 91, 92 (Phe); 94, 107, 108 (Tyr); 117, 131 (Phe); 138 (Leu, Hpro); 152, 166, 180 (Leu) and 186 (Hpro) [19,29-32]. These amino acids are also present in the proteins of peas [33].

The mass spectrum (Fig. 3c) of the low peak (scan 40-50) relates to a fraction comprising 'free' lipids such as fatty acids $\left(\mathrm{m} / \mathrm{z}, 228, \mathrm{C}_{14: 0} ; 256, \mathrm{C}_{16: 0} ; 260 \mathrm{M}-\mathrm{H}_{2} \mathrm{O}, \mathrm{C}_{18: 3}\right.$; $\left.262 \mathrm{M}-\mathrm{H}_{2} \mathrm{O}, \mathrm{C}_{18: 2}\right)$, sitosterols $\left(\mathrm{m} / \mathrm{z}\right.$ 396-414, $\left.\mathrm{C}_{29: 1}\right)$, diglycerides $\left(\mathrm{m} / \mathrm{z} 550, \mathrm{C}_{16: 0,16: 0} ; 576\right.$, $\mathrm{C}_{16: 0,18: 1} ; 596, \mathrm{C}_{16: 0,18: 0}$ and $616, \mathrm{C}_{18: 2,18: 2)}$ and triglycerides $\left(\mathrm{m} / \mathrm{z}, 854, \mathrm{C}_{16: 0,18: 2,18: 2}\right.$ and

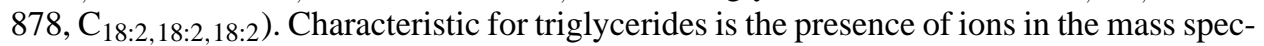
tra that correspond to the loss of a fatty acid carboxyl radical (M-RCOO) from the molecular ion as can be seen at $m / z 574$ and 600. Other ions that correspond to an additional 74 amu to the acylium ion, i.e. $[\mathrm{RCO}+74]$ are also present. These ions are present at $m / z 313\left(\mathrm{C}_{16: 0}\right)$, $337\left(\mathrm{C}_{18: 2}\right)$ and $339\left(\mathrm{C}_{18: 1}\right)$.

\subsubsection{Pisane $H D$}

The EI spectrum (Fig. 4) of Pisane HD is characterized by the following ions: $m / z$ 69, 70, 84, 86, 91, 94, 107, 108, 117, 130, 138, 152, 154, 165, 166, 168, 180, 186, 194 and 208. All these masses have been in found in the mass spectrum of untreated peas (Fig. $3 \mathrm{~b}$ and c) and in protein rich material [21]. The corresponding amino acids are common in the proteins of peas [33]. The masses can be considered as the characteristic protein markers for peas. The ions $m / z 70,84$ and 154 show the highest relative intensity. The mass spectrum shows ions representing lipids: fatty acids $\left(\mathrm{m} / \mathrm{z}, 262\left(\mathrm{M}-\mathrm{H}_{2} \mathrm{O}\right), \mathrm{C}_{18: 2)}\right)$; sitosterols $(\mathrm{m} / \mathrm{z} 396-414$, $\left.\mathrm{C}_{29: 1}\right)$; diglycerides $\left(\mathrm{m} / \mathrm{z}, 574, \mathrm{C}_{16: 0,18: 1}\right.$ and $\left.616, \mathrm{C}_{18: 2,18: 2}\right)$ and triglycerides $(\mathrm{m} / \mathrm{z} 854$, $\mathrm{C}_{16: 0,18: 2,18: 2}$ and 878, $\left.\mathrm{C}_{18: 2.18: 2,18: 2}\right)$. The ions $m / z 313\left(\mathrm{C}_{16: 0}\right)$, and $337\left(\mathrm{C}_{18: 2}\right)$ are present as well. This is well in accordance to the lipids found in the investigated peas.

\section{Optimization of the heating time}

To determine the optimal heating time samples of peas were heated at $T_{\text {oven }}=250{ }^{\circ} \mathrm{C}$ as a function of time. A temperature of $250^{\circ} \mathrm{C}$ was selected, since from this temperature the polysaccharides and proteins start their conversion into compounds that are more resistant to the natural degradation processes. The results of the physical and bulk chemical experiments allowed for a heating time of $60 \mathrm{~min}$ [4]. DTMS-EI experiments were carried out on samples of residues of peas heated at $250{ }^{\circ} \mathrm{C}$ to investigate the change of the chemical nature of the 


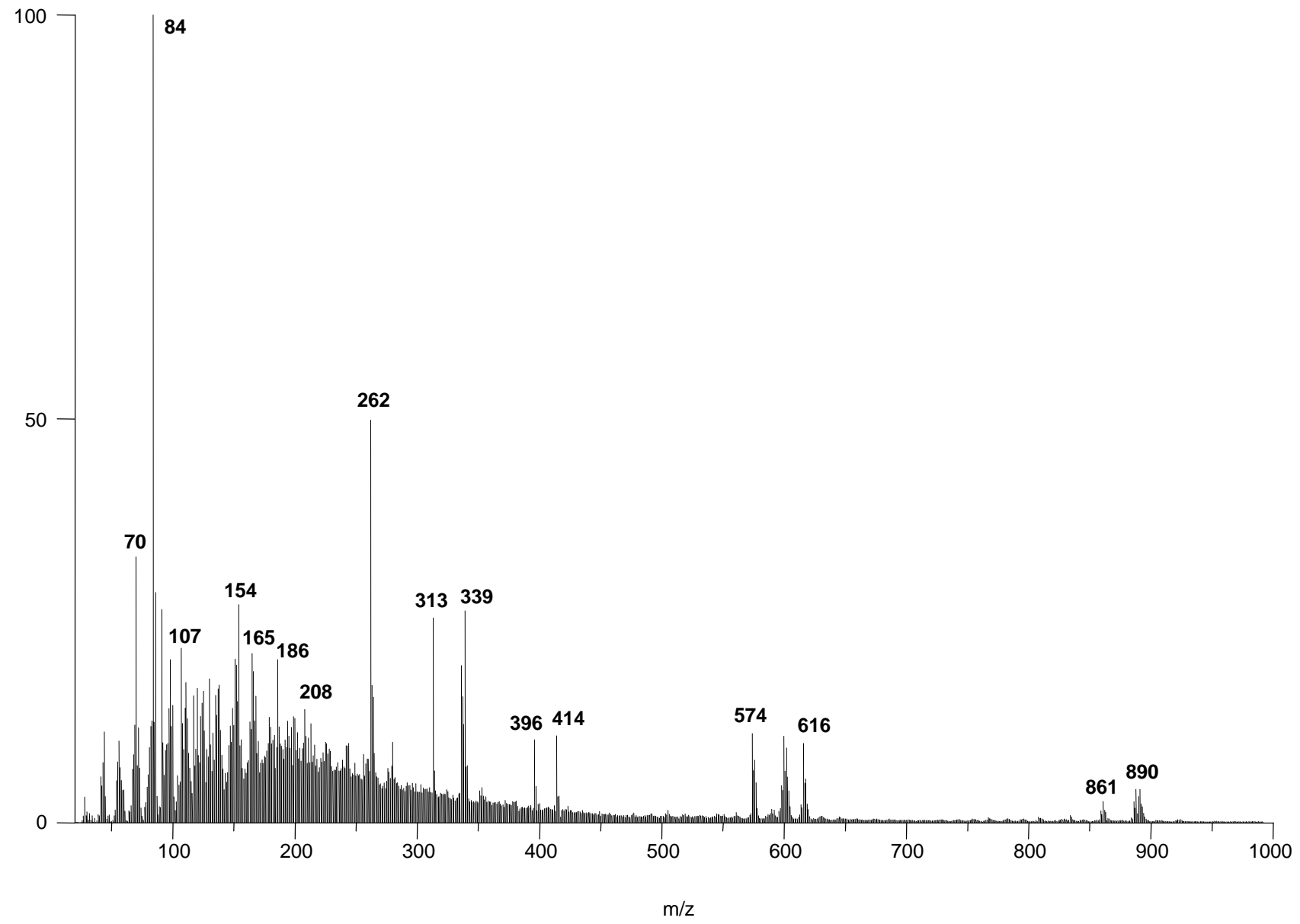

Fig. 4. DTMS (EI) mass spectrum of Pisane HD (pea protein isolate). 
cotyledons as a function of time. The apex $\left(T_{\max }\right)$ of the TIC of the experiments shifts under these conditions to a higher temperature after $45 \mathrm{~min}$ of heating and the TIC traces start to broaden on the high temperature side in samples subjected to more than $37.5 \mathrm{~min}$ of heating. A lower peak at the early stage of the temperature ramp, due to the evaporation of more volatile components (lipids) and a dominant peak at a higher temperature as a result of the dissociation of biopolymeric constituents, characterize the TIC.

The spectrum of the sample of the residue heated for $37.5 \mathrm{~min}$ (not shown) has still an ion distribution that is dominated by masses representing $\operatorname{starch}(m / z 43,57,60$, etc.), proteins $(\mathrm{m} / \mathrm{z} 70$ and 84$)$ and lipids. Masses such as $\mathrm{m} / \mathrm{z}$ 95, 96 and 110 point to the presence of furans. After $45 \mathrm{~min}$ of heating the distribution has changed into an aromatic character showing alkylphenols $(\mathrm{m} / \mathrm{z}, 94$ and 108), alkylbenzenes $(\mathrm{m} / \mathrm{z}, 91$ and 105$)$ and clusters of three mass peaks such as: $m / z 145,146,147 ; 159,160,161 ; 173,174,175$, etc. These clusters correspond to a homologous series of condensed aromatic compounds, of which the even numbered masses are the typical products of heat treatment of polysaccharides, such as cellulose and starch [7,34]. Typical protein markers for untreated peas like $m / z 70,84,117$, 131, etc. are recognized. No further change is observed in the spectra of the samples of residues heated for $60 \mathrm{~min}$ (Fig. 10a) and $120 \mathrm{~min}$ (not shown). Masses representing lipids (i.e. $m / z$ 228, 262, 396-414, 596, 616, 854 and 878) continue to be present.

The DA of the EI spectra that are the result of heating at $250{ }^{\circ} \mathrm{C}$ as a function of time is presented in Fig. 5. The score plot of the first discriminant function (DF1) describes $30 \%$ of the total variance of $82 \%$ between the mass spectra of the samples. The higher functions are disregarded. The full mass range of 20-1000 was used. DF1 describes the changes in the molecular composition as a function of the heating time. The chemical changes accelerate up to $15 \mathrm{~min}$ to be followed by a first plateau till $30 \mathrm{~min}$; a similar plateau is observed in the graph of the weight loss versus time [4]. Next the changes accelerate again to the final plateau at $45 \mathrm{~min}$. $\mathrm{DF}^{-}$corresponds primarily to mass peaks characteristic for hexose and pentose polysaccharides in untreated peas that decrease as the temperature rises. $\mathrm{DF} 1^{+}$characterises the solid residue as the result of the heat treatment. The chemical composition, as described by $\mathrm{DF} 1$, remains stable for heating times above $45 \mathrm{~min}$ at $250^{\circ} \mathrm{C}$. For this reason a heating time of $60 \mathrm{~min}$ is considered sufficient.

\section{Description of the molecular composition of heat-treated material}

\section{1. $\mathrm{DTMS}-\mathrm{CI}-\mathrm{NH}_{3}$}

\subsubsection{Heat-treated Pisane HD}

Protein markers were not clearly recognized in untreated peas under CI conditions. In order to be able to recognize these markers in heated peas Pisane HD was heated at 310, $370,400,440$ and $500^{\circ} \mathrm{C}$ for $60 \mathrm{~min}$. The spectrum of Pisane $\mathrm{HD}$ heated at $T_{\text {oven }}=310^{\circ} \mathrm{C}$ (Fig. 6a) shows identical mass peaks as present in the spectrum of untreated Pisane HD (Fig. 2), but the relative intensity is substantially increased, especially $\mathrm{m} / \mathrm{z} 101,115$ and 146 reaching a relative intensity of almost $100 \%$ and $\mathrm{m} / \mathrm{z} 226$ reaching $75 \%$. In addition a new series of ions is recognized consisting of $\mathrm{m} / \mathrm{z} 147,161,175,189$, etc. Heating experiments with microcrystalline cellulose [35] attributed this series to pyrolysis products of 

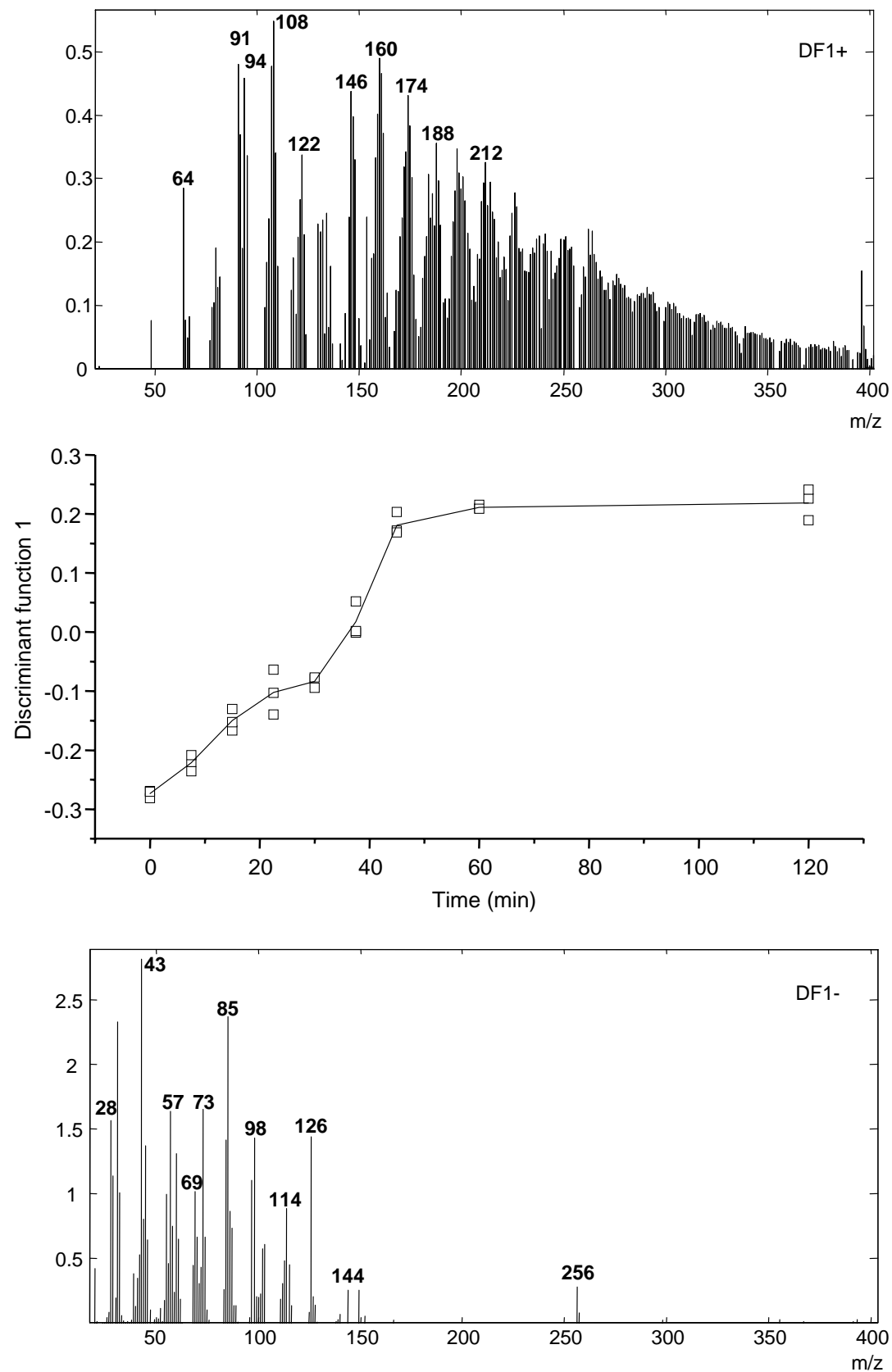

Fig. 5. Score plot from discriminant analyses of DTMS (EI) measurements of untreated and heat-treated $\left(250^{\circ} \mathrm{C}\right)$ Pisum sativum (var. GE) as a function of time. Each sample was analysed in triplicate. $\mathrm{DF} 1^{+}$and $\mathrm{DF} 1^{-}$are the "numerically extracted" mass spectra responsible for the separation into polysaccharides-rich and aromatics-rich samples, respectively. 

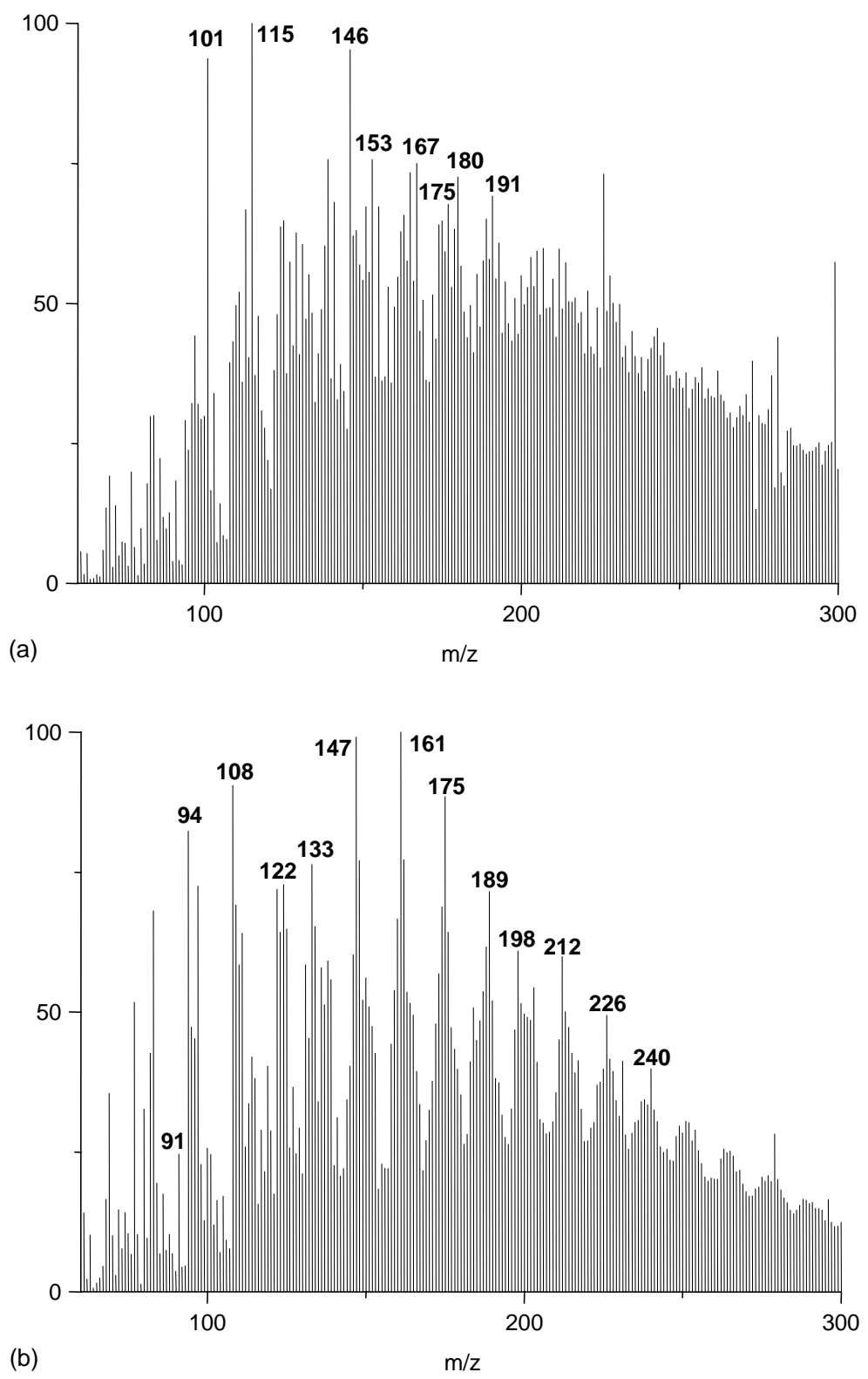

Fig. 6. DTMS (CI) (a) mass spectrum of heat-treated $\left(310^{\circ} \mathrm{C}\right)$ Pisane HD (pea protein isolate) and (b) mass spectrum at $400^{\circ} \mathrm{C}$.

polysaccharides. However, as the content of carbohydrates in Pisane HD is maximum 4.5\%, these ions are to be considered as indicative for the formation of $\mathrm{N}$-containing heterocyclic compounds [36]. The spectrum of Pisane HD heated at $T_{\text {oven }}=400{ }^{\circ} \mathrm{C}$ (Fig. 6b) shows a different mass distribution. The protein markers as present in the sample heated at $250{ }^{\circ} \mathrm{C}$ 
show a much lower relative intensity, but $\mathrm{m} / \mathrm{z}, 101$ and 115 still reach a relative intensity of $30 \%$ and 146 of $70 \%$. Alkylphenols $(\mathrm{m} / \mathrm{z}, 94,108$ and 122), alkylbenzenes $(\mathrm{m} / \mathrm{z}, 91,105$ and 119 ) and the ion series $\mathrm{m} / \mathrm{z}, 147,161,175$ and 189 are prominent. At higher temperatures these ions become less prominent and at $T_{\text {oven }}=500{ }^{\circ} \mathrm{C}$ only $\mathrm{m} / \mathrm{z} 94$ is recognized. Compared with the sample of Pisane HD heated at $250{ }^{\circ} \mathrm{C}$ the TIC has shifted from 60 to 90 scans for the sample heated at $440{ }^{\circ} \mathrm{C}$ pointing to a much higher degree of condensation.

\subsubsection{Residues of heat-treated peas}

The CI spectra of the samples of residues 130-220 (not shown) are similar to that of the untreated pea (Fig. 1). At $T_{\text {oven }}=235^{\circ} \mathrm{C}$ the relative intensity of the higher masses indicative of the polysaccharides decreases. From $T_{\text {oven }}=250{ }^{\circ} \mathrm{C}$ the TIC starts to broaden on the high temperature side. The apex is shifting to a higher temperature, but remains constant for samples of residues heated at higher oven temperatures. The shift points to the presence of an increased amount of more condensed thermally stable material. The chemical changes that accompany these features are expressed in their mass spectra.

The spectrum of the sample of residue 250 (Fig. 7a) shows the first major changes in comparison to the spectrum of the untreated pea. Concerning the polysaccharides the oligosaccharide pyrolysis products at $m / z$ 384, 402, 414, 474, 504 and higher, representing hexosan and pentosan moieties, are no longer present. On the other hand, monosaccharides with attached sugaring-cleavage fragments such as $\mathrm{m} / \mathrm{z} 222$ and 240 show a higher relative intensity in the solid residue. The mass spectrum also shows an increase in the relative intensity of $\mathrm{m} / z 128\left[\mathrm{M}+\mathrm{NH}_{4}\right]^{+}$corresponding to a compound with a molecular weight of 110 . This ion $(\mathrm{m} / \mathrm{z}, 128)$ has been identified as the pseudomolecular ion of different furan moieties with the same mass [35], which are known to be pyrolysis products of carbohydrates.

A new series of ions with odd numbered masses like $m / z$ 147, 161, 175, 189, 201 and 213 starts to appear at $T_{\text {oven }}=270{ }^{\circ} \mathrm{C}$ in the summated spectrum from scan 90 to 115 at the high temperature side of the TIC (Fig. 7b). It shows the beginning of a new thermostable phase, which is characteristic for heat-treated polysaccharides, in this case starch and represent condensed aromatic units [34]. As described above this series is also present in the spectrum of the heated samples of the protein isolate Pisane HD containing 90\% protein.

The spectrum of the samples of the residues 290 (not shown) shows an increase of the odd numbered masses that are observed in the spectrum of residue 270 (Fig. $7 \mathrm{~b}$ ). The spectrum of the sample of residue 310 (Fig. 7c) shows that $\mathrm{m} / \mathrm{z} 162$ has still a relative intensity of $100 \%$ and $\mathrm{m} / \mathrm{z} 180$ of $70 \%$, which means that structurally intact anhydromonosaccharide moieties can still be released from the residues even when they have been heated to $310^{\circ} \mathrm{C}$ for $60 \mathrm{~min}$. From $T_{\mathrm{oven}}=250^{\circ} \mathrm{C}$ the character of the spectra is changing from a number of single polymers into a three-dimensional network polymer at $310^{\circ} \mathrm{C}$.

As shown in the spectrum of untreated Pisane HD (Fig. 2) masses such as $m / z$ 101, 115, 146 and the series $\mathrm{m} / \mathrm{z}, 153,167$, etc. can be considered as protein markers. In the spectra of untreated peas and those heated up to $235^{\circ} \mathrm{C}$ protein markers are not very well recognized under CI conditions. This changes from $250{ }^{\circ} \mathrm{C}$ when the relative intensities of these ions become stronger. For example, at $T_{\text {oven }}=310^{\circ} \mathrm{C}$ (Fig. 7c) the relative peak intensities reach $95 \%$ for $\mathrm{m} / \mathrm{z} 101,70 \%$ for $\mathrm{m} / \mathrm{z} 146$ and $50 \%$ for the series $\mathrm{m} / \mathrm{z} 153,167$, etc. At $400{ }^{\circ} \mathrm{C}$ (Fig. 7d) these relative intensities reduced considerably and at $440^{\circ} \mathrm{C}$ are not observed 

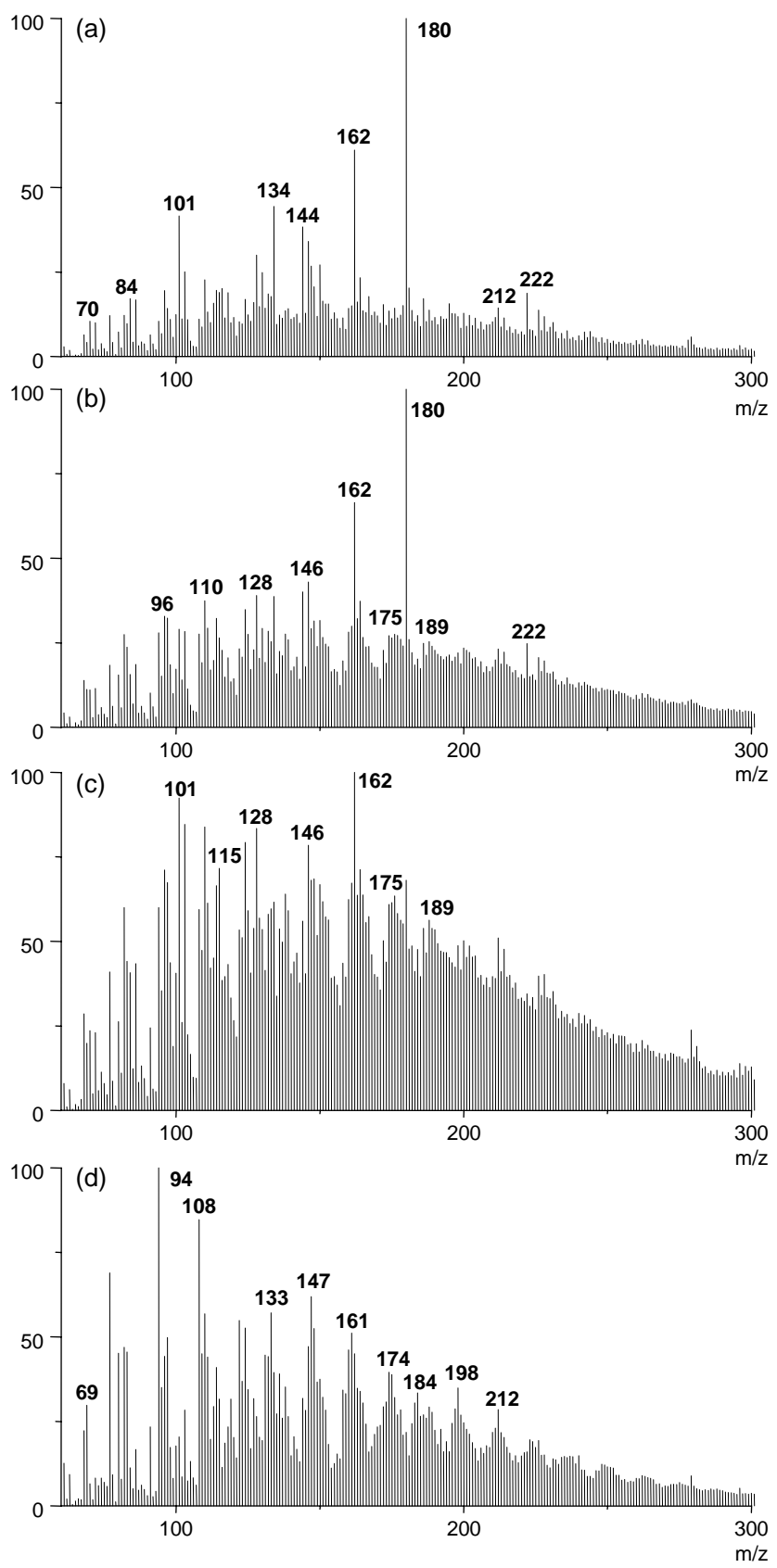

Fig. 7. DTMS (CI) measurements of heat-treated Pisum sativum (var. GE): (a) mass spectrum of residue 250; (b) mass spectrum of residue 270 (scans 90-100) showing ions representing condensed aromatic compounds; (c) mass spectrum of residue 310 and (d) mass spectrum of residue 400 . 
anymore. From $T_{\text {oven }}=310^{\circ} \mathrm{C}$ the alkylphenols and alkylbenzenes, as recognized in heated Pisane HD, are present up to the samples heated at $440^{\circ} \mathrm{C}$. The odd numbered series $\mathrm{m} / \mathrm{z}$ $147,161,175$, etc. has a strong presence at $400^{\circ} \mathrm{C}$ (Fig. $7 \mathrm{~d}$ ) and is still present at $440^{\circ} \mathrm{C}$. The series can be attributed to pyrolysis products from polysaccharides (condensed aromatic compounds) as well as from proteins (N-containing heterocyclic compounds). High resolution data could resolve this ambiguity, but such experiments are not possible under DTMS conditions on our instrument. The heating experiments with microcrystalline cellulose [34] do not allow for a comparison, as the highest temperature during these experiments was $310^{\circ} \mathrm{C}$ only.

The TIC of residue 250 (Fig. 8a) was studied by the time-resolved mass chromatograms (MCs) of the following ions: $\mathrm{m} / \mathrm{z}$ 150, 162, 180, 342, 504, 150, 222 and 240 (hexoses and pentoses) and 101 and 146 (protein markers). The apex of the trace has shifted to a higher temperature compared with the trace of the untreated pea (Fig. 1). Protein markers $\mathrm{m} / \mathrm{z}$ 101 and 146 appear at a low temperature together with anhydro-oligosaccharides like $\mathrm{m} / \mathrm{z}$
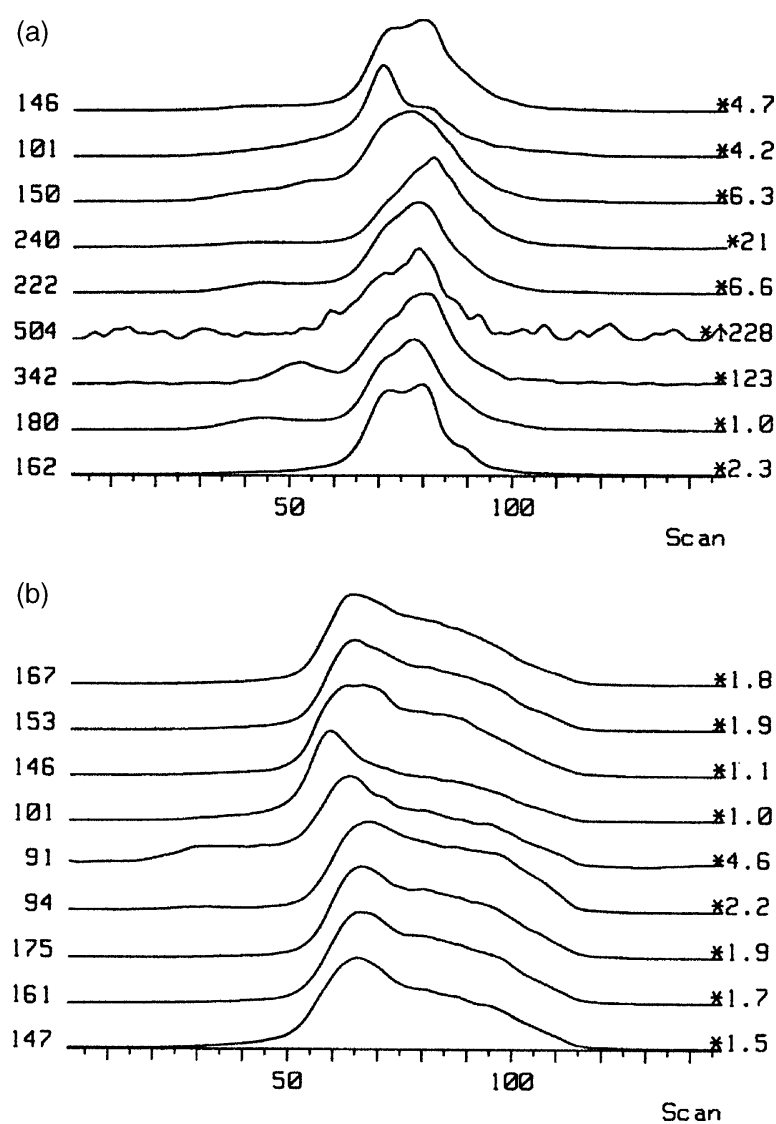

Fig. 8. DTMS (CI) mass chromatographs of heat-treated Pisum sativum (var. GE): (a) for the indicated compounds of residue 250 and (b) for the indicated compounds of residue 290. 
180, 162, 150, 222 and 240. Both the $\mathrm{m} / \mathrm{z}, 146$ and the anhydromonosaccharides $\mathrm{m} / \mathrm{z} 222$ and 240 have a second peak at higher temperatures. It means that ion $\mathrm{m} / \mathrm{z}, 146$ represents a protein marker as well as a deoxysugar. At $T_{\text {oven }}=290^{\circ} \mathrm{C}$ (Fig. 8b) the shape of the trace of the protein markers $(\mathrm{m} / \mathrm{z}, 101$ and 146) has hardly changed, but the relative intensity has increased. The odd-numbered masses $\mathrm{m} / \mathrm{z}$ 147, 161, 175, etc. show two peaks, one at 65 and a second one at 85 scans. This indicates the presence of two identical series of masses, which are pyrolysis products of either polysaccharides or proteins.

DTMS-NH $\mathrm{N}_{3}-\mathrm{CI}$ spectra of the samples of untreated peas and residues 130-400 were subjected to discriminant analysis. The first discriminant function (DF1) describes $46 \%$ and the second discriminant function (DF2) $21 \%$ of the characteristic variance. The higher functions were disregarded. The full mass range of 60-1000 was used. The score map (Fig. 9) describes the relative differences in the molecular composition of the samples plotted as discriminant scores as a function of the oven temperature. DF1 describes the conversion of the polysaccharides into aromatic compounds. DF2 shows the presence of protein markers at $250{ }^{\circ} \mathrm{C}$ and the conversion of these into heterocyclic compounds, alkylphenols and alkylbenzenes at $440^{\circ} \mathrm{C}$. This is shown in the product axes A, B and C and their "numerically extracted" spectra, which are incorporated in the score map of Fig. 9. It shows the presence of protein markers up to $340^{\circ} \mathrm{C}$ and related aromatic and heterocyclic compounds up to $400^{\circ} \mathrm{C}$. Thus proteinaceous marker moieties can be considered as relatively thermally stable.

\subsection{DTMS-EI}

\subsubsection{Heat treated Pisane HD}

DTMS-EI experiments were carried out on samples of Pisane HD heated for $60 \mathrm{~min}$ at the various oven temperatures. The EI spectrum of the sample heated at $310^{\circ} \mathrm{C}$ (Fig. 10a) is characterized by a prominent presence of ions, which are related to alkylated phenols and benzenes such as $m / z$ 91, 92, 94, 105, 107, 108, 119 and 122. Next a homologous series of odd numbered masses $(\mathrm{m} / \mathrm{z}, 117,131,133,147,161,175,189,199,213,227$, etc.) is observed, which have been tentatively attributed to N-containing heterocyclic compounds [36]. An identical series is recognized in the CI spectrum (Fig. 7d). The ions $\mathrm{m} / \mathrm{z}, 70$ and 84 are still present. The spectrum also shows masses related to lipids (i.e. $\mathrm{m} / z$ 396-414 from sitosterol $\mathrm{C}_{29: 1}$ ). The spectrum of the sample heated at $400^{\circ} \mathrm{C}$ (Fig. 10b) is practically identical to that of $310^{\circ} \mathrm{C}$, but the series of odd numbered masses is decreasing. Now the dominant peaks are even numbered $(\mathrm{m} / \mathrm{z} 146,160,174$, etc.). This phenomenon becomes stronger at higher temperatures. At $440{ }^{\circ} \mathrm{C}$ the spectrum (Fig. 10c) is characterized by a strong presence of the ions $\mathrm{m} / \mathrm{z} 27,41$ ( $\mathrm{N}$-containing fragments representing $\mathrm{HCN}$ and $\mathrm{CH}_{3} \mathrm{CN}$ ), 28 (CO), 78 (benzene) and 91, 92, 94, 107, 108, 117, 122 and 131. The series of even numbered masses is still present. In the spectrum of $500^{\circ} \mathrm{C}$ the only ions present are $\mathrm{m} / \mathrm{z} 27(\mathrm{HCN}), 28(\mathrm{CO}), 44\left(\mathrm{CO}_{2}\right), 64\left(\mathrm{SO}_{2}\right), 78$ (benzene) and 92 (toluene).

\subsubsection{Pea residues heated for 60 min at a constant temperature}

DTMS-EI measurements were also carried out on samples of the residues of peas heated at the various oven temperatures. The TIC traces show a sharp product distribution with temperature until $T_{\text {oven }}=235^{\circ} \mathrm{C}$. The traces start to broaden at the high temperature side 

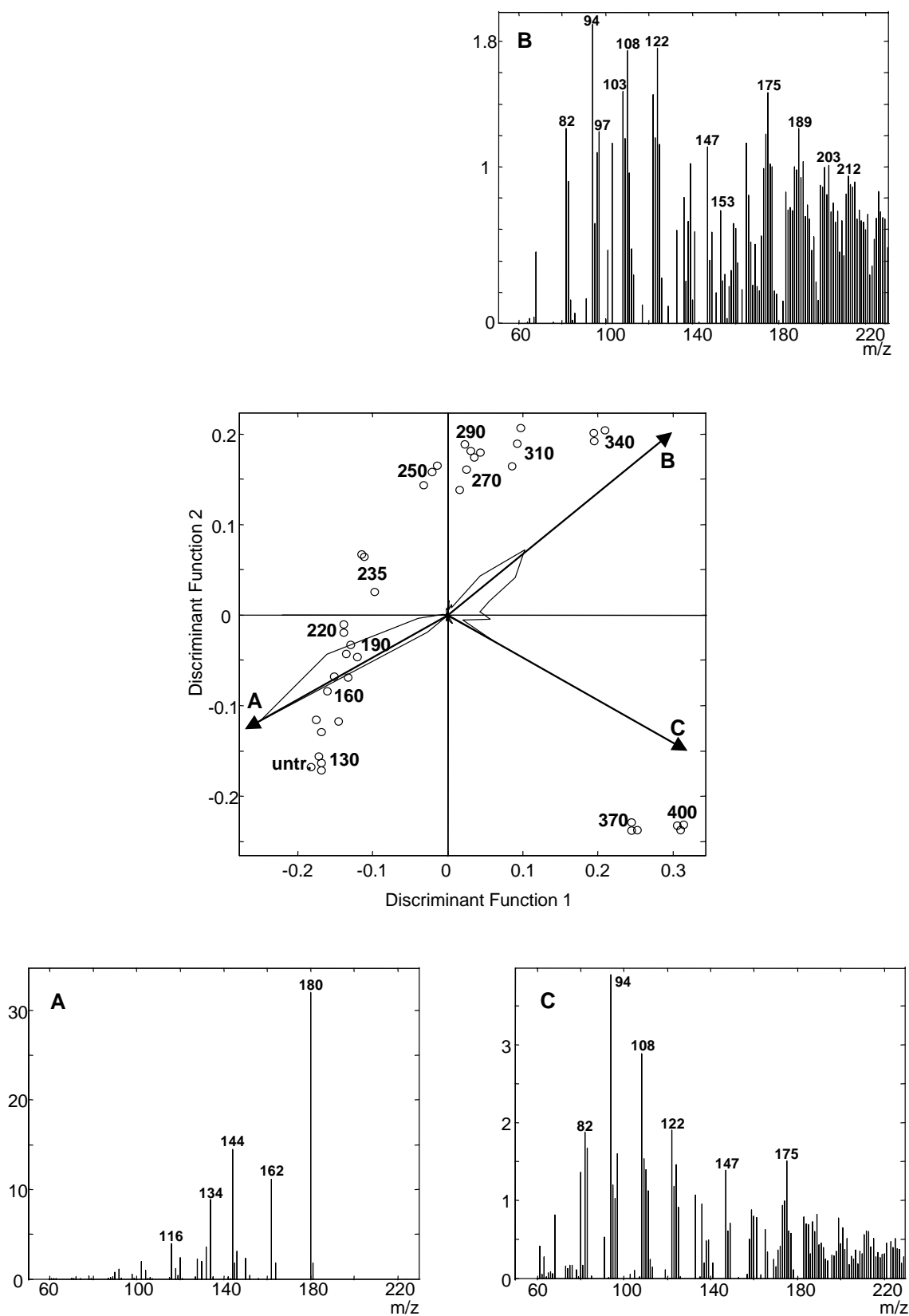

Fig. 9. Score plot from discriminant analyses of DTMS (CI) measurements of untreated and heat-treated Pisum sativum (var. GE). Each sample was analysed in triplicate. The heating temperatures (in ${ }^{\circ} \mathrm{C}$ ) are indicated in the figure. Product axes A, B and C are superimposed and the "numerically extracted" mass spectra for each axis is shown. 

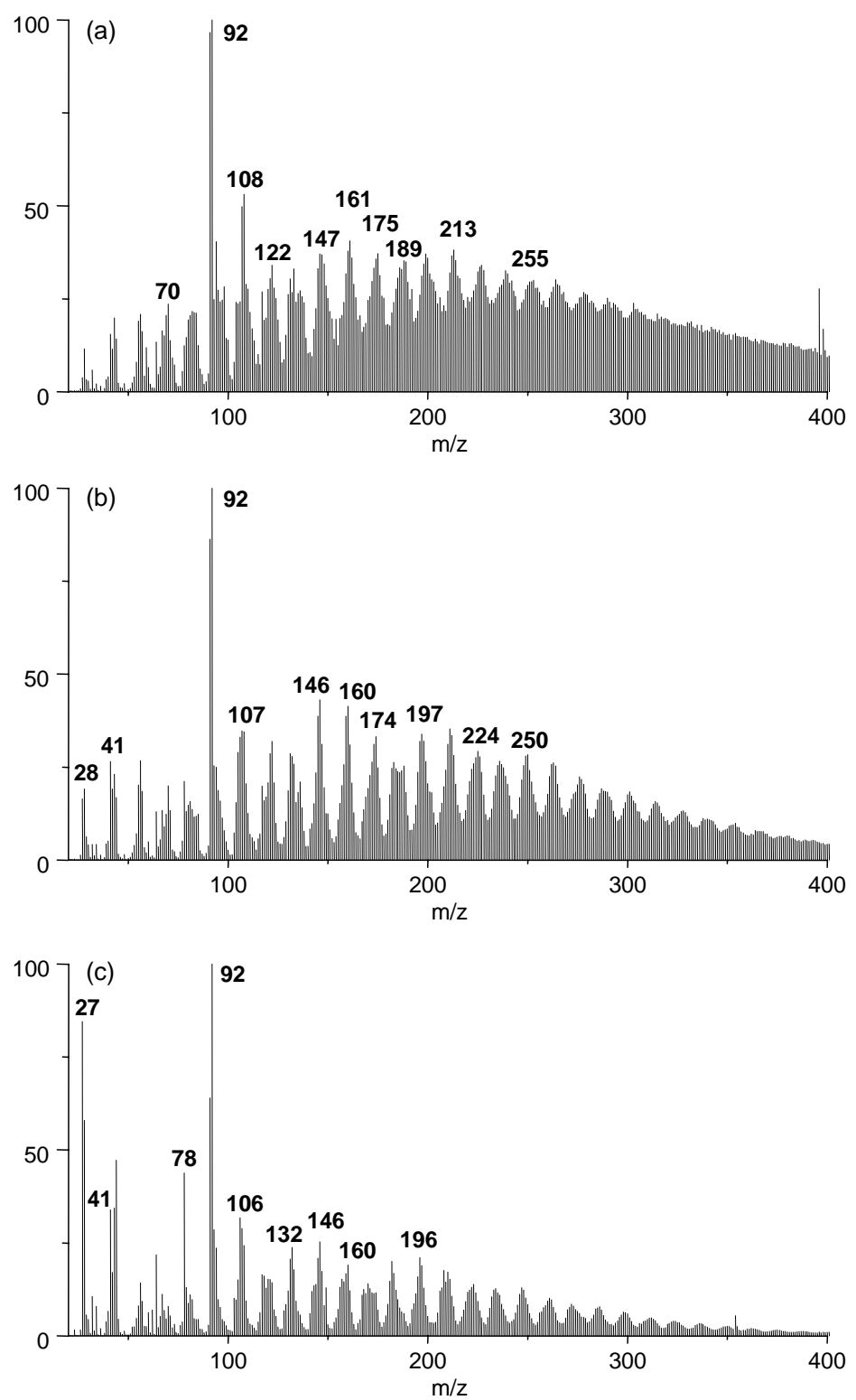

Fig. 10. DTMS (EI) (a) mass spectrum of heat-treated Pisane HD (pea protein isolate) at $310^{\circ} \mathrm{C}$; (b) at $400^{\circ} \mathrm{C}$ and (c) at $440^{\circ} \mathrm{C}$.

from $T_{\text {oven }}=250{ }^{\circ} \mathrm{C}$. The apex of the traces remains constant until $T_{\text {oven }}=235^{\circ} \mathrm{C}$, than rises until $T_{\text {oven }}=290{ }^{\circ} \mathrm{C}$ to remain constant until $T_{\text {oven }}=440^{\circ} \mathrm{C}$. At temperatures above $T_{\text {oven }}=440^{\circ} \mathrm{C}$ the TIC becomes very irregular indicative of instrumental noise due to very low amounts of detectable compounds. 
The EI spectra of the samples of residues 130 until 220 have a similar mass distribution as the untreated pea (Fig. 3b). The spectrum of residue 235 (not shown) points to changes in the distribution of the individual masses compared with the previous spectra and new mass peaks are observed. These phenomena are enhanced in the spectra of residue 250 (Fig. 11a). The masses show the presence of furans $(\mathrm{m} / \mathrm{z}, 95,96$ and 110), alkylphenols $(\mathrm{m} / \mathrm{z}, 94,107,108,121$ and 122), alkylbenzenes $(\mathrm{m} / \mathrm{z} 91,105$ and 119) and clusters of three mass peaks with $\left(\mathrm{CH}_{2}\right)$ mass increments such as: $\mathrm{m} / \mathrm{z} 146,147,148 ; 160,161,162$; $174,175,176 ; 186,187,188 ; 198,199,200 ; 212,213,214$; etc. The clusters correspond to a homologues series of condensed aromatic compounds, of which the even numbered masses are the typical products of heat treatment of polysaccharides, such as cellulose and starch [7,34]. In the spectra of residue 270 (not shown) and higher the characteristic masses of polysaccharides are no longer observed. The masses representing furans are still present. New are the masses for alkylphenols, alkylcatechols, alkylbenzenes and condensed aromatics as shown above. The mass distribution does not change from residue 270 until residue 310 (not shown), when furans are no longer present. From residue 340 (Fig. 11b) to residue 400 the spectra change into a new mass distribution characterized by the presence of the masses $\mathrm{m} / z 78$ (benzene), 91 and 107 (alkylbenzenes) and 64 ( $\mathrm{SO}_{2}$ from sulfates), while at the same time the masses that represent the alkylphenols, alkylcatechols and the condensed aromatics have disappeared. The amount of pyrolysis products in the spectra of the residues 440 (Fig. 11c), 500, 600 and 700 is very low and decreases as a function of temperature. The spectrum of residue 700 (not shown) shows mass $m / z 44\left(\mathrm{CO}_{2}\right)$ and a homologous series of masses $m / z 83,97,111$, etc., fragment ions from aliphatic moieties. This latter series is considered to be background noise, as they are present in the blanks and in the all the summated spectra from the low temperature side of the TIC traces.

The protein markers $(\mathrm{m} / \mathrm{z} 69,70,81,84,138,152,154,166$, etc.), as observed in the spectra of the samples of untreated Pisane HD (Fig. 4) and peas (Fig. 3b), are prominent up to residue 290. From residue 250 in addition to the ions $\mathrm{m} / \mathrm{z} 117$ and 131 more odd-numbered ions are observed. Two series can be distinguished, firstly $m / z$ 117, 131, 145, etc., alkylindole from Try and secondly $\mathrm{m} / \mathrm{z}, 147,161,175$, etc. Both series are attributed to N-containing heterocyclic compounds and are recognized up to residue 400 [36]. From residue 440 (Fig. 11c) the spectra are characterized by the presence of ions that represent $\mathrm{N}$-containing compounds like $m / z 27(\mathrm{HCN})$ and $41\left(\mathrm{CH}_{3} \mathrm{CN}\right)$, both pyrolysis products from amino acids [37], while CO is still released. It shows that proteins and/or residues of amide structures are present in the residues 440 and higher. Proteinaceous moieties are clearly a rather thermally stable material.

The volatile fraction of lipids is still present in residue 310 , but they are no longer observed in residue 340.

The phenomena that accompany the changes as a function of temperature are studied using DA for samples of untreated peas and the residues 130-440. Residues from temperatures higher than $440{ }^{\circ} \mathrm{C}$ were ignored because not enough detectable pyrolysable material is present. The scores of the samples on the first and the second discriminant function are presented in a score map (Fig. 12). The first two functions describe, respectively, 29 and $20 \%$ of the total variance. The higher functions are disregarded. The full mass range of 20-1000 was used. 

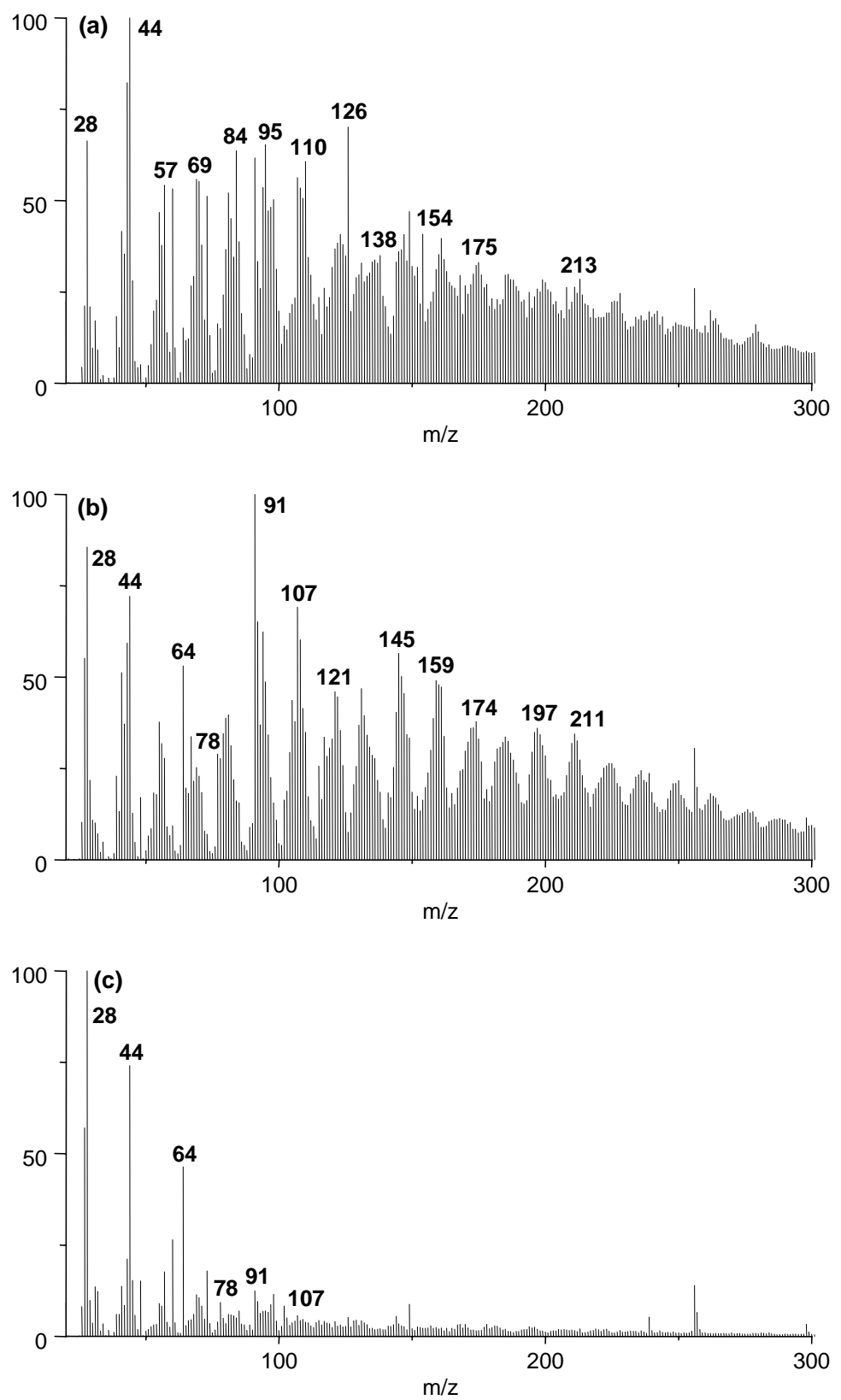

Fig. 11. DTMS (EI) measurements of heat-treated Pisum sativum (var. GE): (a) mass spectra of residue 250; (b) residue 340 and (c) residue 440 . 

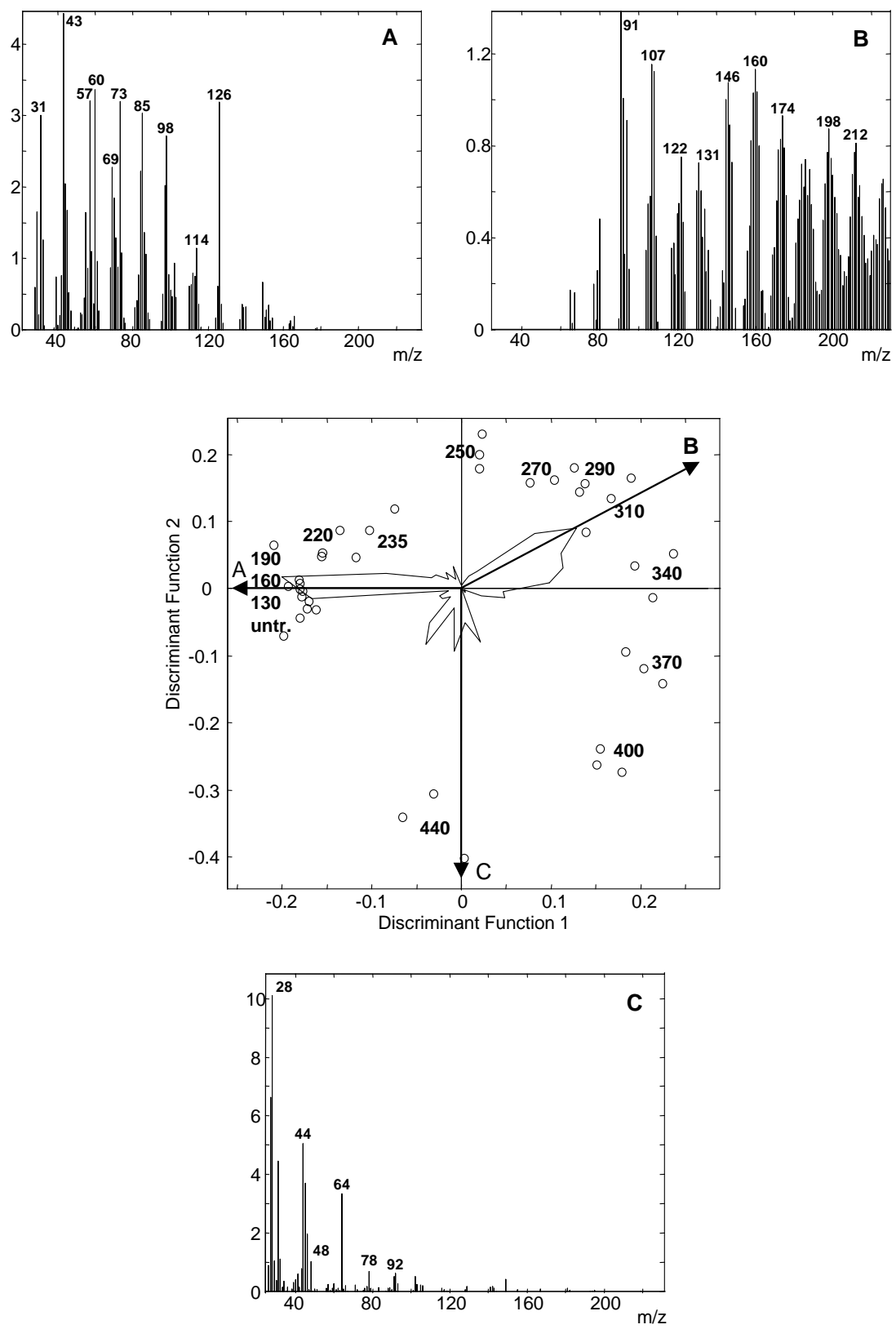

Fig. 12. Score plot from discriminant analyses of DTMS (EI) measurements of untreated and heat-treated Pisum sativum (var. GE). Each sample was analysed in triplicate and the heating temperatures (in ${ }^{\circ} \mathrm{C}$ ) are indicated in the figure. Product axes A, B and C are superimposed and the "numerically extracted" mass spectra for each axis is shown. 
Each discriminant function, plotted as a discriminant spectrum, is characterized by a number of specific masses that are the pyrolysis products of the relevant samples of the residues. These products originate from the three main components of the cotyledons of peas: polysaccharides, proteins and lipids. The variance diagram, incorporated in Fig. 11, shows three directions in which the mass variables of several classes in the discriminant space tend to cluster. The chemical nature of each axis is visualized by their 'numerically extracted' spectra A, B and C, each showing the masses that are typical.

In spectrum A, masses are visible that represent polysaccharides, proteins and lipids as described above. The centre of the cluster represents the samples of the untreated pea (the reactant) and the low temperature residues 130, 160 and 190.

Spectrum B, corresponding to residue 310 , shows the masses representing alkylphenols $(\mathrm{m} / \mathrm{z}, 94$ and 108), alkylbenzenes $(\mathrm{m} / \mathrm{z} 78,91,92,105)$, condensed aromatic and heterocyclic compounds. This shows the conversion of the reactant into a thermally more stable material that is characterized by the masses in the extracted discriminant spectrum.

Spectrum C (residue 440) is characterized by the presence of masses that are attributed to $\mathrm{HCN}(\mathrm{m} / \mathrm{z}, 27), \mathrm{CO}(\mathrm{m} / \mathrm{z} 28), \mathrm{CO}_{2}(\mathrm{~m} / \mathrm{z} 44), \mathrm{SO}(\mathrm{m} / \mathrm{z} 48), \mathrm{SO}_{2}(\mathrm{~m} / \mathrm{z} 64)$, benzene $(\mathrm{m} / \mathrm{z}, 78)$, and alkylbenzenes $(\mathrm{m} / \mathrm{z} 91$ and 105). This extracted mass spectrum is also the result of the conversion of the reactant, but in this case into a tertiary material that differs from the one characterized by spectrum B.

\section{DTMS-EI experiments on sample $\mathbf{H 4 1 4}$ from the archaeological record}

The yield of detectable masses in the spectrum of sample H414 (Fig. 13) is low. The series of masses $m / z 83,97,111$, etc. is considered as background, as explained above. Ions indicating the release of $\mathrm{CO}, \mathrm{CO}_{2}$ and $\mathrm{HCN}$ are observed. The $\mathrm{H} 414$ spectrum is identical to spectra of the residues of recent peas heated for $60 \mathrm{~min}$. at $440{ }^{\circ} \mathrm{C}$ and higher.

\section{Discussion}

Pea seeds contain a mixture of polysaccharides, proteins and minor amounts of fat and inorganic compounds that are present naturally. Starch is the bulk material; protein can reach $25 \mathrm{wt} . \%$ [14]. By heat treatment both compounds will convert at different rates and by different pathways, depending on the experimental conditions. The conversion of starch can be compared with that of cellulose, because the chemical composition and structure can be considered identical for this purpose cf. van der Kaaden et al. [23]. Heat treatment of cellulose is widely reported and numerous papers have dealt in detail with this issue $[38,39]$. The conversion of proteins and the interaction between starch and proteins is a lesser studied issue. In an earlier paper the changes of the physical and bulk chemical properties of pea seeds upon heat treatment has been reported [4]. The changes that occur correspond to a classification in five stages (Fig. 14). Results, such as shown in the score plot of Fig. 12, could be interpreted as if the physical and molecular changes, resulting from heating, are recorded continuously as a function of the oven temperature, similar to a thermo gravimetric technique. This latter technique can be considered as one process with 


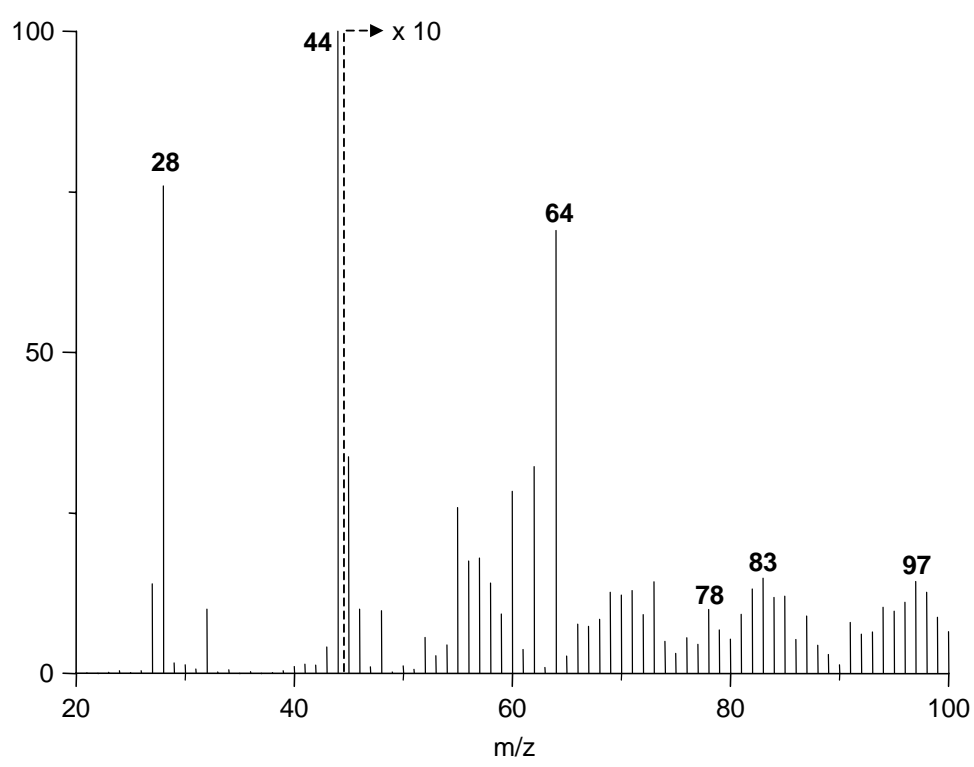

Fig. 13. DTMS (EI) mass spectrum of the archaeological sample H414.

a constant heating rate resulting in one residue. However, in the experimental set-up used in this case each residue is obtained through a separate process and in total 15 experiments were performed to obtain the 15 residues. This set-up was used to simulate the drop of peas into an open fire, where the temperature will differ as a function of the place in the fire. Thus each experiment took place in a pre-heated oven and has a different heating rate, increasing as a function of the oven temperature. The physical data of the heating of peas at $T_{\text {oven }}=250^{\circ} \mathrm{C}$ as a function of time shows, that the weight loss remains constant after ca. 40 min of heating [4]. The DA of the DTMS-EI experiments (Fig. 5) shows that from ca. $40 \mathrm{~min}$ the molecular composition does not change either (for $250^{\circ} \mathrm{C}$ ). The time to reach the stage of constant weight loss and the constant molecular composition decreases considerably with increasing $T_{\text {oven }}$. Consequently, the average heating rate increases from a slow $4{ }^{\circ} \mathrm{C} \mathrm{min}{ }^{-1}$ at $T_{\text {oven }}=235^{\circ} \mathrm{C}$ to a moderate $175^{\circ} \mathrm{C} \mathrm{min}^{-1}$ at $T_{\text {oven }}=700^{\circ} \mathrm{C}$ [4]. The oven temperature and accompanying heating rate of each experiment determines the mechanism and pathway that will take place. The result will be a residue typical for the temperature of each experiment and its accompanying regimen.

\subsection{Polysaccharides}

The DTMS-CI-NH $\mathrm{NH}_{3}$ spectrum of a sample of untreated peas is dominated by $\mathrm{m} / \mathrm{z} 180$, a cluster ion of ammonia with the molecular ion of levoglucosan. This ion is followed by a series of anhydro-oligosaccharides with and without attached ring-cleavage fragments (Fig. 1). These products point to, respectively, a transglycosidation and a $(2+2+2)$ cycloreversion mechanism [18]. Both mechanisms are operating at the same time and will reduce 


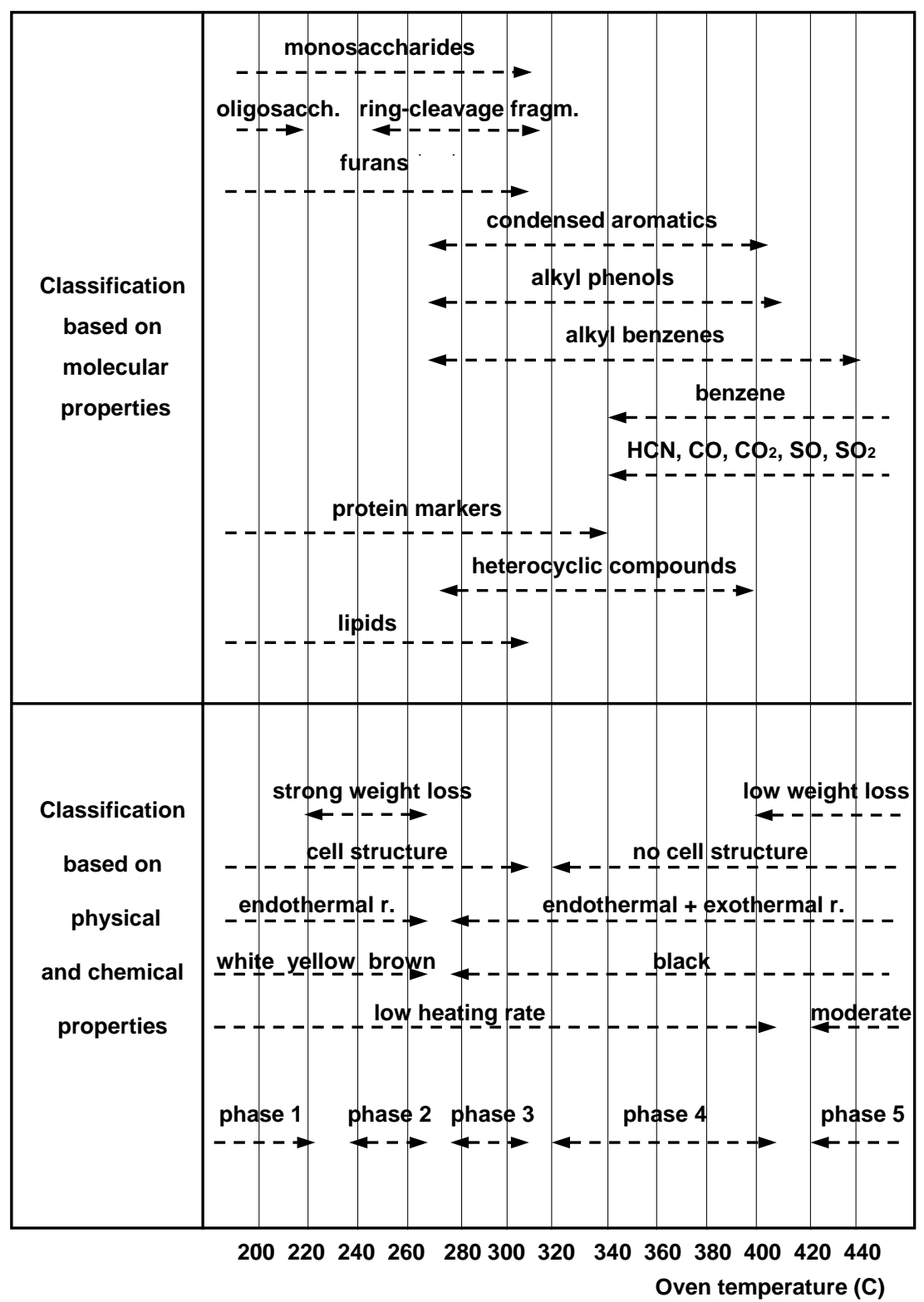

Fig. 14. Classification of untreated and heat-treated, for $60 \mathrm{~min}$., Pisum sativum (var. GE) based on the molecular properties compared with the physical and bulk elemental properties from Braadbaart et al. [4].

the initial polymer size by in-chain cleavages. The spectra of residue 130 up to residue 235 still contain domains with oligosaccharides, but in residue 250 the relative amount is reduced and mainly monosaccharidic constituents appear to be present as witnessed by the MCs (Fig. 8a). Monosaccharidic moieties are still present in residue 310, although the rela- 
tive amount of sugar units with attached ring-cleavage fragments is increased in the spectra. Concurrently, from residue 270 new elements, such as furans, phenols and other aromatic compounds become increasingly more important. It should be noted that the aromatic compounds could be pyrolysis products from polysaccharides as well as from proteins. The corresponding solid matter is thermally more stable as is shown by the corresponding TIC traces. Not only the apex of the pyrolysis events has shifted to a higher temperature, but the traces have also broadened towards the higher temperature side. The compounds that are released at the higher temperatures are the compounds released from new, more aromatic, networks. This indicates that the thermally labile polysaccharide rich material has changed into a thermally more stable material enriched in an aromatic substructure. The results show that the proposed model as presented by Boon et al. [8], on the formation of a thermostable polymer network at oven temperatures higher than $270{ }^{\circ} \mathrm{C}$ in the residues of pyrolyzed microcrystalline cellulose is also applicable to a thermally modified polysaccharide/protein rich biomass such as whole peas. In this model residual non-volatile glucose cores with attached ring-cleavage fragments as a result of $(2+2+2)$ cycloreversion reactions act, increasingly from $T_{\mathrm{oven}}=250^{\circ} \mathrm{C}$, as aldolcondensation sites for volatized compounds that will react with larger non-volatile residual structural elements. In the spectra of heated peas this can be observed by the increasing presence of $\mathrm{m} / z 222$ and 240 in the spectra, which occurs simultaneously with the appearance of the aromatic compounds characteristic for the residues up to $310^{\circ} \mathrm{C}$. The polymer network will change from a carbohydrate-dominated reactant into a material with mainly aromatic compounds in residue 310 . The linear polysaccharide polymer has changed into a growing network polymer. It is clear that the performed CI experiments provide detailed insight into the conversion of polysaccharides, the bulk fraction of peas, as a result of heating.

Apart from the CI studies DTMS-EI experiments were carried out on samples of untreated peas and the set of thermal residues of peas. DA was performed on samples up to residue 440. The distribution of the samples in the discriminant score plot based on EI-data (Fig. 12) is governed by the progressive heating of the samples in the set of residues. The evolution of the various classes of compounds, which are represented by specific masses, is a function of the oven temperature and thus the heating rate of each experiment. It shows that until residue 235 polysaccharides, proteins and lipids are observed with a distribution of the mass peaks in the spectra that remains unchanged. From residue 250 the polysaccharide rich material changes progressively into an aromatic material which is most pronounced in residue 310. The lower temperatures and slower heating rates result in a preference for the path that produces solids and gases. The exothermal reaction (Fig. 14) is the result of secondary reactions between converting solids and the gases traversing the residue on the way to the external environment. The confined structure of the pea enhances the production of secondary products. The linear polymer has thus changed into a growing network polymer, which is thermally more stable. This newly formed thermally stable polymer system dissociates further at higher temperatures and a disproportionation occurs by loss of $\mathrm{CO}$ and $\mathrm{CO}_{2}$ leading to a highly condensed aromatic polymer. From residue 340 the mass spectra show a considerable increase of the relative intensities of the corresponding masses $\mathrm{m} / \mathrm{z} 28$ and 44, respectively. Simultaneously the following masses show a higher relative intensity in sequence of their relative abundance: $\mathrm{m} / \mathrm{z} 78$ (benzene), 27 (HCN), 28, 44, 48 (SO) and $64\left(\mathrm{SO}_{2}\right)$. The presence of $\mathrm{HCN}$ indicates that nitrogen is built in the residue; $\mathrm{SO}$ and $\mathrm{SO}_{2}$ 
are attributed pyrolysis products of sulfates or sulphonates or from compounds like $\mathrm{CaSO}_{4}$, formed during the heating process. The sample of residue 440 shows that functionalized hetero aromatic compounds are not present anymore and only alkylbenzenes are released. The masses $m / z$ 27, 28, 44, 48, 64 and 78 are still observed. At higher oven temperatures the relative intensity of these masses progressively decreases and in the spectrum of residue $700 \mathrm{~m} / \mathrm{z} 44$ is present only. The process results in a carbon rich material in residue 500 with no signs of secondary reactions suggesting a primary product through volatization reactions. The path to form volatiles at these high oven temperatures is clearly stronger than the formation of secondary products [40]. The higher heating rates contribute to this result. The pyrolysis of high-ranking coals (anthracite) shows that the same ions are released as in residue 500 and higher [41], suggesting a high similarity of high ranking coals and the residues formed in this study.

\subsection{Proteins}

Processes are different for the proteins present in peas. Proteins are heteropolymers that dissociate thermally into a large number of compounds. DTMS of proteins, therefore, have a tendency to show unresolved envelopes of mass peaks. The CI experiments of Pisane HD, however, do show a number of characteristic protein markers (Fig. 2). This mass distribution does not show a strong difference with the spectrum of the sample heated at $310^{\circ} \mathrm{C}$ (Fig. 6a). The main differences are the increase of the relative intensities of the protein markers and the beginning of a homologous series of odd-numbered masses: $m / z$ 147, 161, 175, etc. At higher temperatures the mass distribution changes. New mass peaks representing alkylphenols and alkylbenzenes are recognized and become stronger up to a heating temperature of $400{ }^{\circ} \mathrm{C}$ (Fig. 6b). Moreover the relative intensity of the protein markers decreases and the series of odd-numbered masses increase in relative intensity. This implies that CI experiments, for samples heated up to $310^{\circ} \mathrm{C}$, are not very useful for discriminating between untreated and heat treated samples of a protein isolate, i.e. Pisane HD, from peas. However, the mass peaks of the compounds generated from untreated and heated Pisane HD are not present in the spectra of untreated peas and residue 130 up to 250 . From residue 250 the protein markers are present in all the spectra of the residues of peas and can be considered as a fingerprint of protein markers. Thus the method is a very useful tool to indicate the presence of proteins in residues of peas heated at temperatures higher than $250{ }^{\circ} \mathrm{C}$.

The reference spectra of Pisane HD under DTMS-EI show the relevant markers for the presence of proteins and for $\mathrm{N}$-containing compounds (odd mass peaks). The spectra reveal that protein mass markers are present up to the sample heated at $310^{\circ} \mathrm{C}$ (Fig. 10a). The homologous series of masses present in the spectra of Pisane HD (from the sample heated at $250^{\circ} \mathrm{C}$ ) are almost identical to those that are generated from polysaccharides [7]. Also the masses representing alkylphenols and alkylbenzenes are present in both heated polysaccharides and proteins. This suggests that thermal treatment of proteins and polysaccharides leads to solid residues that are increasingly similar. EI and CI experiments, under nominal mass measuring conditions, fail to discriminate between pyrolysis products of polysaccharides and proteins, as present in peas, at heating temperatures between 250 and $400{ }^{\circ} \mathrm{C}$. At higher temperatures $\mathrm{N}$-containing compounds, such as $\mathrm{HCN}$ and $\mathrm{CH}_{3} \mathrm{CN}$, are still observed up to a heating temperature of $440^{\circ} \mathrm{C}$. The presence of $\mathrm{HCN}$ in the spectra up to this 
temperature is considered as a marker for the presence of such $\mathrm{N}$-containing compounds, although their chemical structure is unknown. FTIR shows that $\mathrm{CN}$ moieties as such are not present, but there are indications for in chain nitrogen in an aromatic main structure. All $\left(\mathrm{CH}_{2}\right)$ moieties have completely disappeared.

Untreated peas and residue 130 up to 340 , under EI conditions, show the relevant protein markers. From residue 270 up to 400 alkylphenols, alkylbenzenes and the homologous series are observed. These masses are pyrolysis products of starch and proteins. Small molecules, such as $\mathrm{HCN}$ and $\mathrm{CH}_{3} \mathrm{CN}$ can be recognized up to residue 700. This suggests that under EI conditions protein derived structural moieties can be observed up to heating temperatures of $340^{\circ} \mathrm{C}$. Proteinaceous moieties also show a clear difference between the pyrolysis products of the residues heated at temperatures lower and higher than $440^{\circ} \mathrm{C}$. At temperatures lower than $440{ }^{\circ} \mathrm{C}$ the residues show volatile matter with a recognizable chemical relationship to the native polymer and as such no structural resemblance is lost. At higher temperatures and heating rates more highly condensed solid material is formed that releases $\mathrm{CO}, \mathrm{CO}_{2}, \mathrm{HCN}$, $\mathrm{SO}$ and $\mathrm{SO}_{2}$. More hetero atoms are built in into the aromatic network. From elemental analyses it is known that nitrogen $(5 \mathrm{wt} . \%, \mathrm{DAF})$ and sulphur $(0.27 \mathrm{wt} . \%, \mathrm{DAF})$ are still present in residue 700 [4].

\subsection{Lipids}

The masses representing lipids are recognizable in the EI experiments of the sample of Pisane HD as well as in the samples of peas and their pyrolytic residues up to residue 310 . Although this is surprising at first hand it is postulated that those lipids are chemically bound or strongly adsorbed inside the residues.

\subsection{Implications for the archaeology}

The results of the experiments show that after $60 \mathrm{~min}$ exposure up to a temperature of $270{ }^{\circ} \mathrm{C}$ the molecular composition of the residues of recent peas mainly consist of polysaccharides and proteins. When these residues are deposited into the soil they will be microbially degraded, as untreated peas will be. The phase between 270 and $310^{\circ} \mathrm{C}$ consists of polysaccharides, proteins, heterocyclic and aromatic compounds and it is not sure if these residues or parts of the residues will survive the various degradation processes. The residues heated at temperatures higher than $310^{\circ} \mathrm{C}$ will have a better chance to be found in the archaeological record, however proteinaceous marker compounds seem to be present up to $340^{\circ} \mathrm{C}$ and their residues at much higher temperatures.

The results of the EI experiments on sample H414 shows that its spectrum has an identical mass distribution as the spectra of residue 440 and higher, which suggests that this pea residue has been exposed to at least $440{ }^{\circ} \mathrm{C}$. The vitrinite reflection measurements on polished specimens support this [4].

\section{Summary: classification of heat-treated pea solids}

The original product (peas) and the new products, resulting from the heating process, are visualized together with the physical and bulk chemical changes [4] (Fig. 14). It shows that 
both the latter and molecular changes can be conveniently considered into identical stages. Cotyledons are the bulk material of peas and are enclosed by the seed coat. The cells in the cotyledons contain large starch grains, protein bodies and small deposits of fats. The cell walls consist mainly of non-starchy polysaccharides. Thus peas have a rather confined structure. Based on analytical mass spectrometry (DTMS-CI and-EI) the conversion of the intact polysaccharide/protein rich cotyledons is described as a function of the temperature. The actual experimental conditions allow for a heating rate that increases from a slow ca. $4{ }^{\circ} \mathrm{C} \mathrm{min}^{-1}$ at a heating temperature of $235^{\circ} \mathrm{C}$ to a moderate ca. $175^{\circ} \mathrm{C} \mathrm{min}^{-1}$ at $700^{\circ} \mathrm{C}$. This results in different paths of conversion.

Polysaccharides and/or proteins show a strong dehydration and produce a brown product up to $270{ }^{\circ} \mathrm{C}$, the result of Maillard reactions. In residue 270 the polysaccharidic and proteinaceous material is still dominating. At higher temperatures a path that produces thermally more stable products determines the conversion. Three types of products can be distinguished as a function of the heating temperature. The first one, from 270 to $310^{\circ} \mathrm{C}$, is characterized by the presence of monosaccharides, protein fragments and aromatic compounds. From $270{ }^{\circ} \mathrm{C}$ the reactions show also an exotherm, explaining the presence of secondary products. This second type, from $310^{\circ} \mathrm{C}$ up to a transitional stage from 400 to $440{ }^{\circ} \mathrm{C}$, consists of various aromatic and heterocyclic compounds. The third type, at higher temperatures, is a tertiary product that releases alkylbenzenes, $\mathrm{CO}, \mathrm{CO}_{2}, \mathrm{HCN}, \mathrm{SO}$ and $\mathrm{SO}_{2}$. In this type of products a path can be distinguished, characterized by a strongly $\mathrm{C}$-enriched material with some remaining hetero atoms in the network structure.

Thus the simulation in the laboratory of the heating provides a rigorous base for studies regarding the effect of the various formation processes, as used in the field of archaeology, on the residues corresponding to the five stages. It suggests that peas should have been heated up to at least $310^{\circ} \mathrm{C}$ before their residues survive natural degradation processes.

\section{Acknowledgements}

The authors are grateful to Dr. A.C. Tas of TNO Nutrition and Food Research, Zeist, The Netherlands for his suggestions regarding the pyrolysis of proteins. This research is supported by FOM research program 49 funded by the Foundation for Fundamental Research on Matter (FOM), a subsidiary of the Dutch Organisation for Scientific Research (NWO).

\section{References}

[1] W. van Zeist, Palaeohistoria 14 (1970) 41.

[2] M.B. Schiffer, Am. Antiquity 48 (1983) 675.

[3] M.B. Schiffer, Formation Processes of the Archaeological Record, University of New Mexico, Albuquerque, 1987 (Chapter 8).

[4] F. Braadbaart, J.J. Boon, H. Veld, P. David, P.F. van Bergen, Journal of Archaeological Science, in press.

[5] A.C. Tas, A. Kerkenaar, G.F. Lavos, J. van de Greef, J. Anal. Appl. Pyrolysis 15 (1989) 55.

[6] J.A. Lomax, J.J. Boon, R.A. Hoffman, Carbohydr. Res. 221 (1991a) 219.

[7] I. Pastorova, R.E. Botto, P.A. Arisz, J.J. Boon, Carbohydr. Res. 262 (1994) 27. 
[8] J.J. Boon, I. Pastorova, R.E. Botto, P.W. Arisz, Biomass Bioenergy 7 (1-6) (1994) 25.

[9] W. Arisz, A. Lomax, J.J. Boon, Anal. Chem. 62 (1990) 1519.

[10] S.S. Deshpande, R.N. Adsule, in: D.K. Salunkhe, S.S. Kadam (Eds.), Handbook of Vegetable Science and Technology, Marcel Dekker, New York, 1998.

[11] J.G. Swift, M.S. Buttrose, Planta 109 (1973) 61.

[12] J.M. Bain, F.V. Mercer, Aust. J. Biol. Sci. 19 (1966) 49.

[13] H.-D. Belitz, W. Grosch, Food Chemistry, second ed., Springer-Verlag, Berlin, 1999.

[14] Y.D. Daveby, M. Abrahamson, P. Åman, J. Sci. Food Agric. 63 (1993) 21.

[15] A.M. Flinn, J.S. Pate, Ann. Bot. 32 (1968) 479.

[16] C.C. Bakels, Analecta Praehistorica Leidensia XI (1978) 176.

[17] V.A. Klap, J.J. Boon, M.A. Hemminga, J. van Stoelen, Mar. Chem. 54 (1996) 221.

[18] J.A. Lomax, J.M. Commandeur, P.W. Arisz, J.J. Boon, J. Anal. Appl. Pyrolysis 19 (1991) 65.

[19] M. Scheijen, Analytical Pyrolysis Studies on Tobacco, Amsterdam, 1991.

[20] A.C. Tas, unpublished results.

[21] J.C.M. van de Arendonk, G.J. Niemann, J.J. Boon, J. Anal. Appl. Pyrolysis 42 (1997) 33.

[22] J. de Waart, A.C. Tas, G.F. La Vos, J. van der Greef, J. Anal. Appl. Pyrolysis 24 (1992) 245.

[23] A. van der Kaaden, J. Haverkamp, J.J. Boon, J.W. de Leeuw, J. Anal. Appl. Pyrolysis 5 (1983) 199.

[24] A. Ohnishi, K. Kato, E. Takagi, Polym. J. 7 (1975) 431.

[25] W. Genuit, J.J. Boon, J. Anal. Appl. Pyrolysis 8 (1985) 25.

[26] R.J. Helleur, J. Anal. Appl. Pyrolysis 11 (1987) 297.

[27] A.D. Pouwels, G.B. Eijkel, J.J. Boon, J. Anal. Appl. Pyrolysis 14 (1989) 237.

[28] A.D. Pouwels, J.J. Boon, J. Anal. Appl. Pyrolysis 17 (1990) 97.

[29] T.I. Eglinton, J.J. Boon, E.C. Minor, R.J. Olson, Mar. Chem. 52 (1996) 27.

[30] J.J. Boon, J.W. de Leeuw, J. Anal. Appl. Pyrolysis 11 (1987) 313.

[31] B.A. Stankiewicz, P.F. van Bergen, I.J. Duncan, J.F. Carter, E.G. Briggs, R.P. Evershed, Rapid Commun. Mass Spectrom. 10 (1996) 1747.

[32] G. Chiavari, G.C. Galletti, J. Anal. Appl. Pyrolysis 24 (1992) 123.

[33] E. Derbyshire, D.J. Wright, D. Boulter, Phytochemistry 15 (1976) 3.

[34] I. Pastorova, T.F.M. Oudemans, J.J. Boon, J. Anal. Appl. Pyrolysis 25 (1993a) 63.

[35] I. Pastorova, P.W. Arisz, J.J. Boon, Carbohydr. Res. 248 (1993) 151.

[36] S.C. Moldoveanu, Analytical Pyrolysis of Natural Organic Polymers, Elsevier, Amsterdam, 1998.

[37] P.G. Simmonds, E.E. Medley, M.A. Ratcliff, G.P. Shulman, Anal. Chem. 44 (1972) 2060.

[38] F. Shafizadeh, A.G.W. Bradbury, J. Appl. Polym. Sci. 23 (1979) 1431.

[39] M.J. Antal Jr., G. Varhegyi, Ind. Eng. Chem. Res. 34 (1995) 703.

[40] J. Piskorz, D. Radlein, D.S. Scott, J. Appl. Anal. Pyrolysis 9 (1986) 121.

[41] P.J.J. Tromp, J.A. Moulijn, J.J. Boon, New Trends Coal Sci. (1988) 241. 